\title{
Evaluation of Tank 241-T-111 Level Data and In-Tank Video Inspection
}

\author{
Author Name: \\ John Schofield, Columbia Energy and Environmental Services \\ Amie Feero, Washington River Protection Solutions, LLC \\ Richland, WA 99352 \\ U.S. Department of Energy Contract DE-AC27-08RV14800 \\ EDT/ECN: DRF UC: NA \\ Cost Center: Charge Code: \\ B\&R Code: $\quad$ Total Pages: 60 JDA 3/17/14
}

Key Words: Tank T-111, leak rate, leak volume

Abstract: This document summarizes the status of tank T-111 as of January 1, 2014 and estimates a leak rate and post-1994 leak volume for the tank.

TRADEMARK DISCLAIMER. Reference herein to any specific commercial product, process, or service by trade name, trademark, manufacturer, or otherwise, does not necessarily constitute or imply its endorsement, recommendation, or favoring by the United States Government or any agency thereof or its contractors or subcontractors.
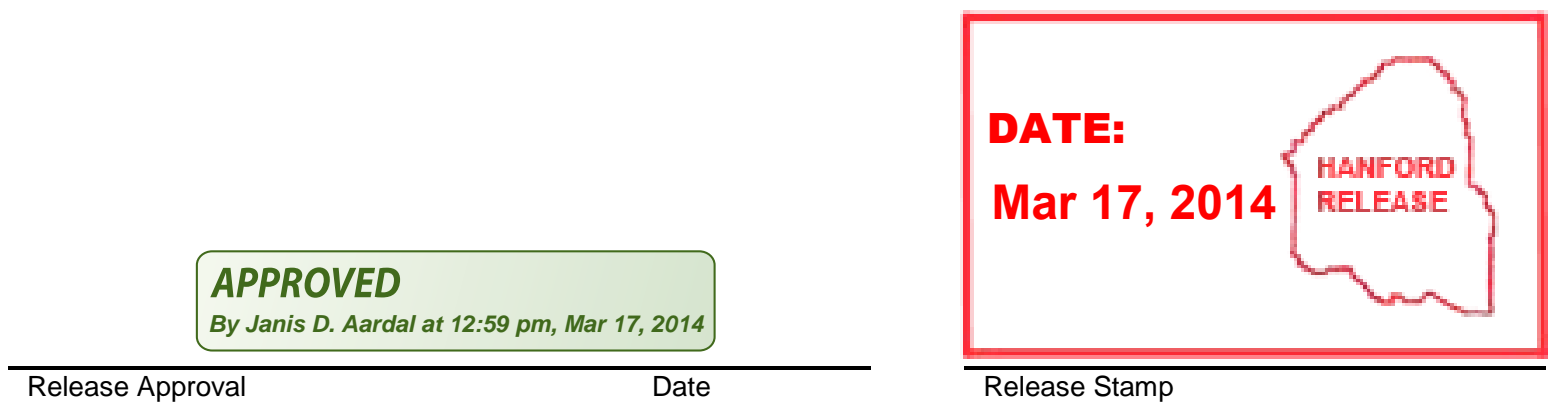

Release Stamp

\section{Approved For Public Release}




\begin{tabular}{|c|c|c|c|}
\hline \multicolumn{2}{|r|}{$\begin{array}{l}\text { Tank Operations Contractor (TOC) } \\
\text { RECORD OF REVISION }\end{array}$} & $\begin{array}{l}\text { (1) Document Number: } \\
\text { RPP-RPT-54964 }\end{array}$ & Page 1 \\
\hline \multicolumn{4}{|c|}{$\begin{array}{l}\text { (2) Title: } \\
\text { Evaluation of Tank 241-T-111 Level Data and In-Tank Video Inspection }\end{array}$} \\
\hline \multicolumn{4}{|c|}{ Change Control Record } \\
\hline \multirow{2}{*}{$\begin{array}{c}(3) \\
\text { Revision }\end{array}$} & \multirow{2}{*}{ (4) Description of Change - Replace, Add, and Delete Pages } & \multicolumn{2}{|c|}{ Authorized for Release } \\
\hline & & (5) Author. (print/sign/date) & (6) Resp. Mgr. (print/sign/date) \\
\hline 1 & Removed OUO designation from each page. & $\begin{array}{l}\text { Dennis Washenfelder } \\
7 / 24 / 13\end{array}$ & $\begin{array}{l}\text { David Little } \\
7 / 25 / 13\end{array}$ \\
\hline RS & $\begin{array}{l}\text { Rewrite of document updating information and } \\
\text { calculations. }\end{array}$ & $\begin{array}{l}\text { Johnschotield } \\
\text { foh tafofall } 1 / 2\end{array}$ & $\begin{array}{l}\text { DGBAIDE } \\
\text { JOBaride } 2 / 26 / 14\end{array}$ \\
\hline
\end{tabular}




\section{TABLE OF CONTENTS}

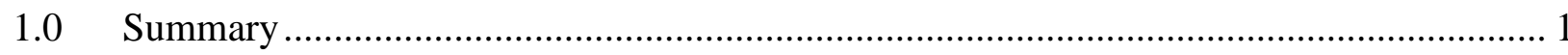

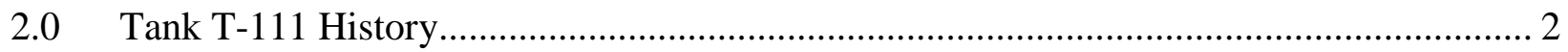

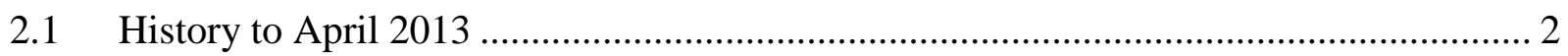

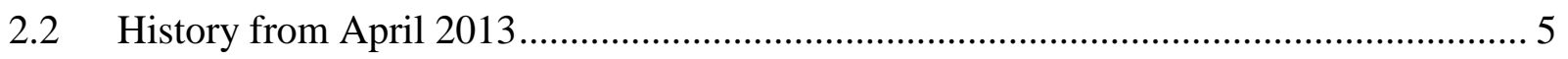

3.0 Tank T-111 In-Tank Video Inspection Results ........................................................ 5

3.1 May 7, 2003 Video from Riser 2 on Northeast Side of Tank …………………............ 5

3.2 February 11 and March 20, 2013 Videos from Riser 6 on Southwest Side of Tank ....... 9

3.3 December 30 and 31, 2013 Videos from Riser 2 on Northeast Side of Tank ................ 13

4.0 Evaluation of Tank T-111 Liquid Level Data Changes .................................................... 20

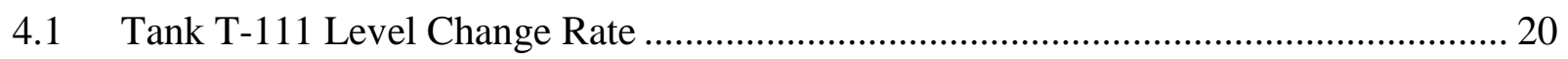

4.2 Tank T-111 Volume Change Rate ....................................................................... 28

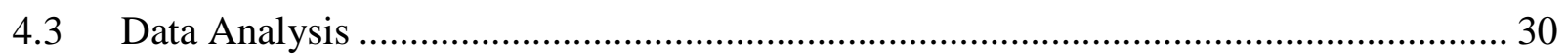

4.3.1 Evaluation of ILL and SL Validity …………................................................... 37

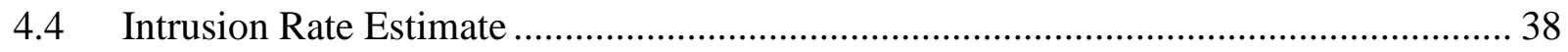

4.5 Evaporation Rate Estimate ................................................................................... 39

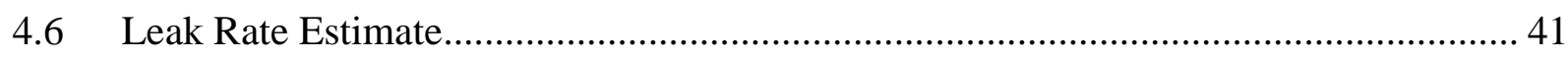

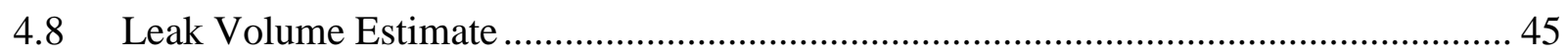

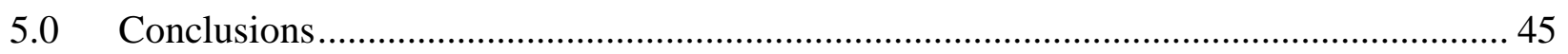

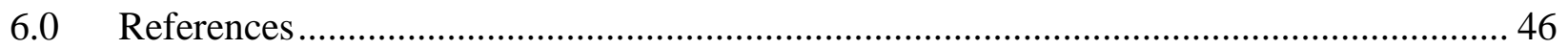

\section{LIST OF TABLES}

Table 1 Tank T-111 Level Change Rates After September 25, 2013 …................................... 25

Table 2 Factors Impacting Surface Level or Interstitial Liquid Level Data ............................... 30

Table 3 Gas Monitoring Data Taken Prior to Tank Entry for Tank T-111 Videos ...................... 35

Table 4 Additional Tank T-111 Headspace Sample Data from TWINS ..................................... 35

Table 5 Tank T-111 ENRAF Gauge Work Packages Since January 1, 2007.............................. 38

Table 6 Radionuclides Contributing Greater Than $0.01 \%$ to the Tank T-111 Waste Heat

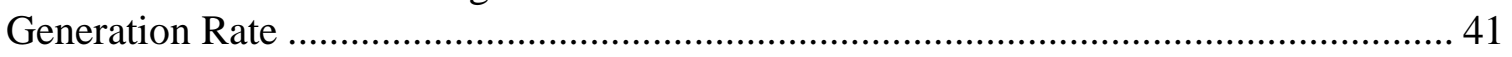

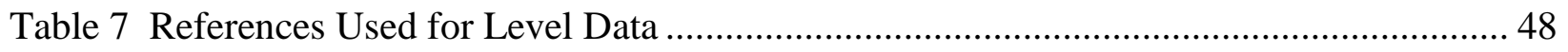




\section{RPP-RPT-54964, Revision 2}

\section{LIST OF FIGURES}

Figure 1 Tank T-111 Interstitial Liquid Level and Adjusted* Surface Level Data..................... 3

Figure 2 Tank T-111 Level Changes for 2011 to 2014 ........................................................ 6

Figure 3 Tank T-111 May 7, 2003 Video Waste Surface Composite ...................................... 7

Figure 4 Tank T-111 Enraf Plummet on May 7, 2003 ........................................................... 8

Figure 5 Anomaly on East Wall of Tank T-111 on May 7, 2003 …..................................... 8

Figure 6 Typical Stalactite on Tank T-111 Top Stiffener Ring Flashing ............................... 10

Figure 7 Possible Past Intrusion Location in Tank T-111 Dome ............................................ 10

Figure 8 Moist Depressions Directly Below Dome Stain in Figure 8 ................................... 11

Figure 9 Anomaly on SE Area of Tank T-111 Dome Just Above Top Stiffener Ring............... 11

Figure 10 Reflections of Drip Ripples from Pool onto Tank T-111 Dome .............................. 12

Figure 11 Tank T-111 Central Dome Area Showing Probable Water Droplets........................ 13

Figure 12 Tank T-111 Enraf Plummet, December 31, 2013 ............................................. 14

Figure 13 Tank T-111 Enraf Plummet and Area Under Riser 3, December 31, 2013 ............. 14

Figure 14 Closeup \#1 of Anomaly on Tank T-111 East Wall, December 31, 2013................. 15

Figure 15 Closeup \#2 of Anomaly on Tank T-111 East Wall, December 31, 2013................. 15

Figure 16 Closeup \#3 of Anomaly on Tank T-111 East Wall, December 31, 2013................. 16

Figure 17 Tank T-111 Showing Water Droplets on Central Dome Area, December 30, 2013... 17

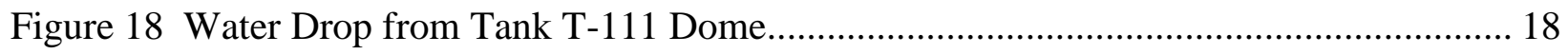

Figure 19 Tank T-111 Waste Surface Panorama from December 31, 2013 ........................... 19

Figure 20 Tank T-111 Initial Level Decrease 1973 - 1974 ............................................... 21

Figure 21 Expanded X-Axis and Y-Axis Plot of Tank T-111 Level Data ............................. 23

Figure 22 Tank T-111 Surface and Interstitial Liquid Level Change Rates to June 13, 2013 .... 24

Figure 23 Tank T-111 Average Liquid Level Change Rates 1973 to June 13, 2013 ............... 26

Figure 24 Tank T-111 Surface and Interstitial Liquid Levels January 1, 2013 to January 1, 2014

Figure 25 Calculated Tank T-111 Volume Change Rate July 13, 1995 to June 13, 2013 ......... 29

Figure 26 Tank T-111 ILL vs. Inverse Barometric Pressure, August 2001 to August 2003 ....... 33

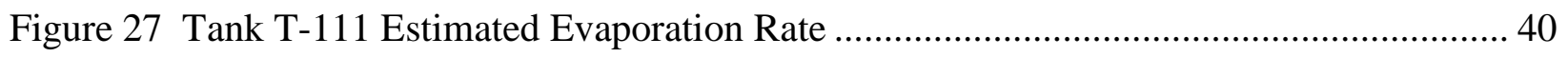

Figure 28 Calculated Tank T-111 Leak Rate as Function of Assumed Intrusion Rate .............. 43

Figure 29 Calculated Tank T-111 Leak Rate for An Average 131 gal/yr Intrusion Rate .......... 44 
RPP-RPT-54964, Revision 2

\begin{tabular}{ll} 
ACRONYMS and ABBREVIATIONS \\
BBI & Best Basis Inventory \\
BTU & British Thermal Unit \\
cfm & cubic feet per minute \\
Ci & curie \\
DST & double-shell tank \\
FIC & Food Instrument Corporation [level gauge] \\
ft & feet \\
gal & gallon \\
in. & inches \\
IHS & Industrial Hygiene and Safety \\
ILL & interstitial liquid level \\
IS & interim stabilization \\
kgal & thousand gallons \\
LOW & liquid observation well \\
mL & milliliter \\
PC-SACS & Personal Computer Surveillance Analysis Computer System \\
ppb & parts per billion \\
ppm & parts per million \\
RH & relative humidity \\
SL & surface level \\
SST & single-shell tank \\
SWIHD & Site Wide Industrial Hygiene Database \\
TWINS & Tank Waste Information Network System \\
yr & year \\
\hline
\end{tabular}




\section{RPP-RPT-54964, Revision 2}

\subsection{Summary}

This report provides an evaluation of the conditions in tank 241-T-111 (T-111) as of January 1, 2014. After evaluating available data and observing in-tank videos it is concluded that the level changes in tank T-111 are due to a combination of intrusion and leaking:

- The leak rate from tank T-111 reached a maximum of about -3.1 gal/day in June 2013 and as of January 1, 2014 was about -1.8 gal/day.

- The post 1994 leak volume as of January 1, 2014 is approximately 2,500 gal.

- The tank is experiencing intrusion and leakage concurrently, and either one or both of these are changing with time.

The leak rate and leak volume are approximations.

Tank T-111 was suspected of leaking in 1974 and most of the pumpable liquid was pumped out at that time. The tank was saltwell pumped using a turbine pump in 1976 to 1978. From 1978 to 1993 the tank had an apparent intrusion of over 1.5 inches. In 1993 the liquid level began to decrease and the tank was suspected of leaking again. A jet pump was installed and additional liquid removed to the extent practical from 1994 to1995. From 1995 to 2006 the tank liquid level had a nominal one inch increase before the liquid level began to drop again. The liquid level decrease rate accelerated with time until June-July 2013, at which time the interstitial liquid level (ILL) leveled out and showed a small rise before beginning to decrease again in late September. The waste surface level (SL) data since June-July 2013 showed a similar pattern, without the small level rise in the summer of 2013.

Tank T-111 is unique among the 149 single-shell tanks (SST) at Hanford in that it has shown cycles since 1979 consisting of a long period of level increase followed by a long period of level decrease. The level decrease period for the first cycle was truncated when the tank was saltwell jet pumped, but the decrease for the second cycle has been going on since the level peaked in late 2006. It is concluded that these cycles are due to the combined effects of intrusion and leaking.

The intrusion rate into tank T-111 appears to have averaged around $130 \mathrm{gal} / \mathrm{yr}$, but has probably varied significantly during the years. The current tank T-111 leak period appears to have begun in the 2000 to 2003 time frame, assuming there was not a major decrease in the intrusion rate at that time. If there was a major decrease in the intrusion rate the current tank leak period may have begun earlier.

This document is an update of Revision 1 which evaluated the tank T-111 SL and ILL behavior through April 1, 2013.

The history of the tank, current conditions, in-tank video results, and basis for the conclusions are provided. This document evaluates conditions in tank T-111 as of January 1, 2014; it is not a formal leak assessment prepared in accordance with TFC-ENG-CHEM-D-42, Tank Leak Assessment Process. A formal leak assessment is not required since the tank is already designated as an assumed leaking tank. 


\section{RPP-RPT-54964, Revision 2}

\subsection{Tank T-111 History}

\subsection{History to April 2013}

Tank T-111 is characterized as an assumed leaker in HNF-EP-0182, Waste Status Summary for Month Ending October 31, 2013, Rev 307. This status is based upon a leak from the tank first being noted in 1974, and the leak again becoming evident in 1993.

Tank T-111 is one of twelve $75 \mathrm{ft}$. diameter tanks in 241-T Tank Farm (T-Farm) constructed between 1943 and 1944 in 200 West Area. The tank has a nominal capacity of $530 \mathrm{kgal}$. Tank T-111 entered service during the fourth quarter of 1945 with a cascade from tank T-110 of second cycle decontamination (2C) waste (RPP-RPT-43169, 2009 Auto TCR for Tank 241-T-111). The tank was filled with $2 \mathrm{C}$ waste, at which time the waste liquid was cascaded to tank T-112. Cascading continued until the third quarter of 1946, when tank T-112 was filled. Nearly all of the supernatant of tank T-111 was transferred out and cascading of $2 \mathrm{C}$ waste resumed in the first quarter of 1948 . When the entire T-110 $\rightarrow \mathrm{T}-111 \rightarrow \mathrm{T}-112$ cascade became full, waste from the last tank (T-112) was transferred to a crib. This cycle continued until the fourth quarter of 1952. From 1952 to $19562 \mathrm{C}$ and lanthanum fluoride waste (224) were sent to tank T-111 with the liquid subsequently transferred to a crib. No waste was added to the tank after 1956.

Figure 1 is a plot of the tank T-111 waste level from 1959 to January 2014. See Table 7 at the end of Section 6.0 for list of level data sources. Although the plot shows a number of minor level changes between 1959 and 1974, these changes are likely due to instrument maintenance or errors in reporting volumes or level data. There are no recorded transfers in or out of the tank from 1956 until the liquid level began to decrease slowly in 1973. The tank was suspected of leaking and most of the supernatant was pumped from tank T-111 in April and May of 1974 (SD-WM-TI-356, Waste Storage Tank Status and Leak Detection Criteria, Rev. 0). The level continued to drop at a decreasing rate from May to October 1974, at which time the waste surface level gauge reading stabilized between 172 and 173 inches and remained there until early 1976. Saltwell pumping using a turbine pump began in 1976 and continued periodically until 1978 (SD-WM-TI-356).

Shortly after pumping was halted the waste level began to rise slowly. The increase continued from 1979 until 1993. In 1993 the level began to decrease and it appeared that the tank was leaking again so a saltwell jet pump was installed and operated beginning in May 1994. Interim stabilization (IS) using the jet pump was complete in 1995 (HNF-SD-RE-TI-178, Single-Shell Tank Interim Stabilization Record, Rev 9A). Following IS pumping the tank T-111 waste level again began to rise slowly. The surface level (SL) increase rate was linear from late 1995 until between 2000 to 2002 when the increase rate began to slow. From 2004 until late 2006 the tank liquid level was essentially constant except for normal annual temperature-influenced fluctuations in the waste surface level. The liquid level began to decrease after 2006 and was still decreasing on April 1, 2013.

The ILL and SL level data for tank T-111 both peaked in late 2006 and have shown decreasing trends since the December 2007 ILL and March 2008 SL, with the negative change rate increasing with time to April 1, 2013. 
RPP-RPT-54964, Revision 2

Figure 1 Tank T-111 Interstitial Liquid Level and Adjusted* Surface Level Data

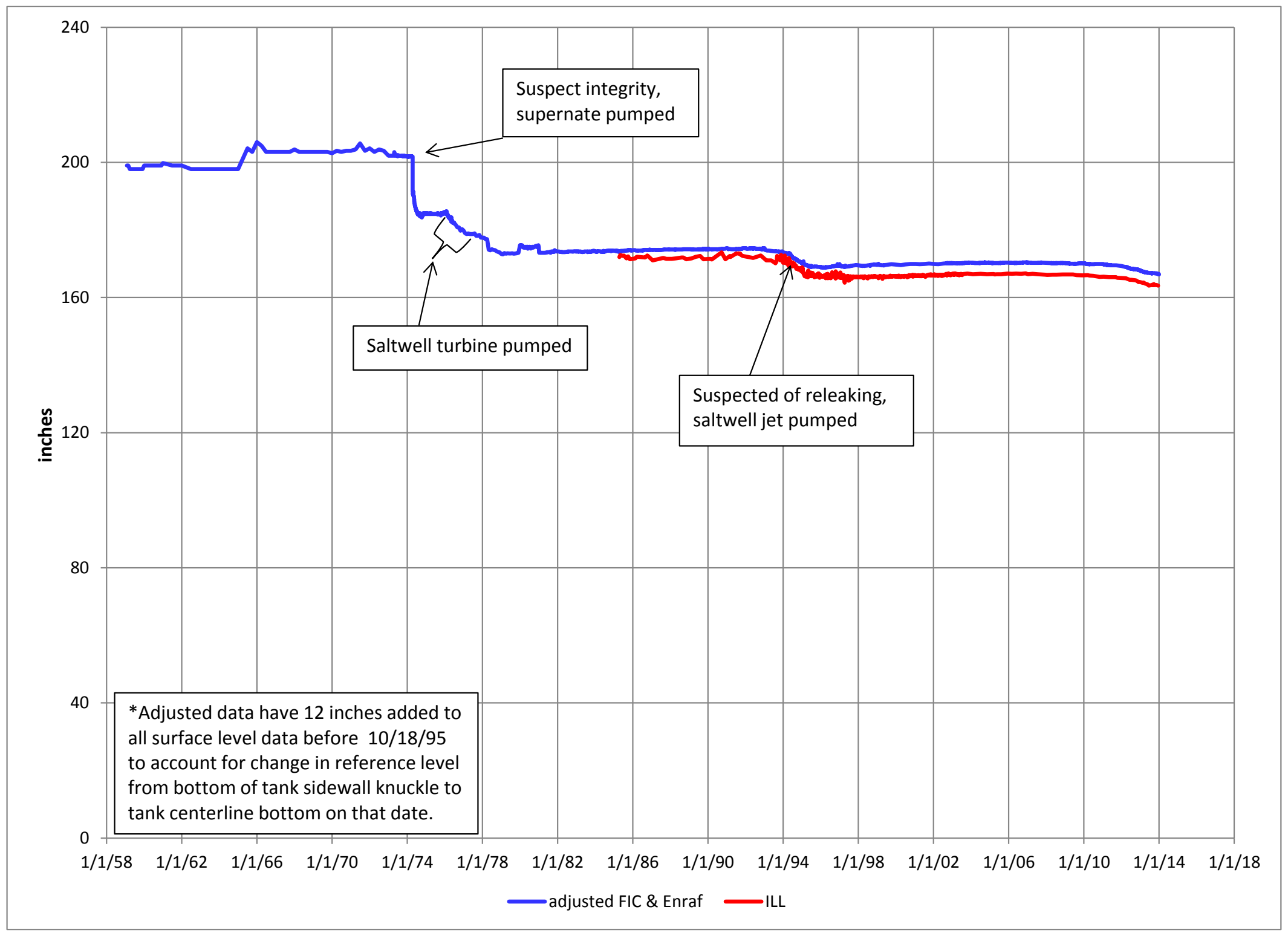


The highest ILL reading was in November 2006. The ILL was being measured quarterly, with the highest reading for 2007 obtained in July. No third quarter 2007 ILL reading was recorded and the ILL measurement in December 2007 showed a 0.096 inch decrease from July. The December reading began a progression of decreasing ILLs.

The highest SL reading was in December 2006 when the waste level was at the peak of its annual cycle. The highest SL reading for 2007 was in September, after which the Honeywell Enraf (Enraf) gauge was out of service until March of 2008. When the Enraf was put back in service the reading was 0.16 inches lower than in September 2007, the reading began the progression of decreasing SLs.

The tank T-111 ILL reading on November 16, 2012 exceeded the lower specification baseline limit in the Personal Computer Surveillance Analysis Computer System (PC-SACS) database. A follow-up ILL reading on November 27, 2013 confirmed the below lower specification limit value, and WRPS-PER-2012-1977 was written on November 27, 2012.

The tank T-111 level decrease trend was noted in the late summer of 2012. A rough evaporation estimate at that time could not account for all the liquid leaving the tank. As a result, the LOW monitoring frequency for the tank was increased and a work package was initiated to obtain an in-tank video. The purpose of the in-tank video was to confirm the tank Enraf gauge was providing valid readings and to determine the fraction of the waste surface which was liquid. The latter is needed for estimating the tank evaporation rate and to correlate a level decrease rate to a volumetric decrease rate.

Failure of a tank liner is normally attributed to thermal stresses, design/construction issues, or corrosion. The tank has never contained thermally hot waste and the tank first leaked about 30 years following the first addition of waste to the tank, so design/construction concerns should have been evident by then. The potential for corrosion of the tank liner significant enough to cause a tank leak is not readily apparent from 1974 tank sample data, but is apparent in 1991. Tank T-111 liquid sample analyses show the liquid in 1974 to have a desirable $\mathrm{pH}$ and thus imply a low corrosion rate. The 1974 samples (Internal Memos R. E. Wheeler to R. L. Walser, Analysis of Tank Farm Samples Sample: T-3304, 111-T, June 7, 1974 and R. E. Wheeler to R. L. Walser, Analysis of Tank Farm Samples Sample: T-4893, 111-T, September 24, 1974, IDMS Accession \#1007130273) showed the $\mathrm{pH}$ ranging from 12.9 to 13.3 with specific gravities ranging from 1.018 to 1.020 . By 1991 the $\left[\mathrm{OH}^{-}\right]$concentration had dropped by a factor of about 1000 and was now in a region where the corrosion rate of the steel liner could increase. Sample results from 1991 (obtained from a Tank Waste Information Network System (TWINS) download on March 21, 2013) showed core sample interstitial liquid $\mathrm{pH}$ ranging from 9.8 to 10.2 with the density ranging from 1.05 to $1.17 \mathrm{~g} / \mathrm{mL}$.

In-tank videos were obtained from tank T-111 on May 7, 2003, February 11, 2013, and March 20, 2013. The May 7, 2003 and February 11, 2013 videos show the Enraf plummet to be providing valid data from a liquid pool in a small depression under the Enraf riser. The ILL can also be observed in a little depression around the LOW in the 2013 videos. The central pool around the saltwell screen was estimated at $20 \mathrm{ft}$. diameter. The liquid level observed by the SL and the ILL calculated by the LOW data are essentially the same surface.

Following the February 11, 2013 video, notification was made by the U. S. Department of Energy that the tank appeared to be leaking. 
In October 2007 the grading began for the T-Farm surface in preparation for the T-Farm interim barrier that was subsequently installed. The T-Farm interim barrier extends over a very small fraction of the tank T-111 surface. This barrier could have altered an intrusion into tank T-111, but since the change in the tank SL and ILL data began several years before this date it is assumed the interim barrier installation did not have a significant impact on the tank T-111 liquid level change rate.

\subsection{History from April 2013}

Figure 2 shows the tank T-111 level changes from 2011 with an expanded $\mathrm{x}$-axis and $\mathrm{y}$-axis so that changes in recent years can be seen better. The tank level changes since the April 1, 2013 cutoff date for the data in Revisions 0 and 1 of this document can be clearly seen. The SL data continued to decrease at about the same rate as before April 2013 until it leveled off in July. It held fairly constant until late September 2013, then began to decrease again. The ILL continued to decrease until the June 13, 2013 reading. The level rose slightly with the next reading on July 26, 2013 and continued to increase until late September 2013 when it began to decrease at about the same rate as the SL. The December 2013 ILL value is about the same as the June 2013 reading.

Additional in-tank videos were obtained from tank T-111 on December 30 and 31, 2013. These videos were obtained from the same riser as the May 7, 2003 video, on the opposite side of the tank from the riser used for the February and March 2013 videos.

\subsection{Tank T-111 In-Tank Video Inspection Results}

\subsection{May 7, 2003 Video from Riser 2 on Northeast Side of Tank}

A video was obtained on May 7, 2003 from riser 6. The video was reviewed in late 2013 and the results are summarized as:

- No intrusions were noted. The waste surface was observed closely throughout the video and no drops were noted falling onto the pool surface. Figure 3 shows the pool surface, the placid appearance is typical of the pool during the video.

- The Enraf plummet is sitting in a small pool of liquid, as shown in Figure 4. A small accumulation of liquid is also seen under adjacent riser 3.

- $\quad$ The strange anomaly noted on the east wall of the tank in the February and March 2013 videos from riser 6 (see Section 3.2) is shown in Figure 5. Note what appears to be a black rod and thin rods or wires leading from the anomaly. See Section 3.3 for further discussion and a closer view of the anomaly from riser 2 in December 2013. 
RPP-RPT-54964, Revision 2

Figure 2 Tank T-111 Level Changes for 2011 to 2014

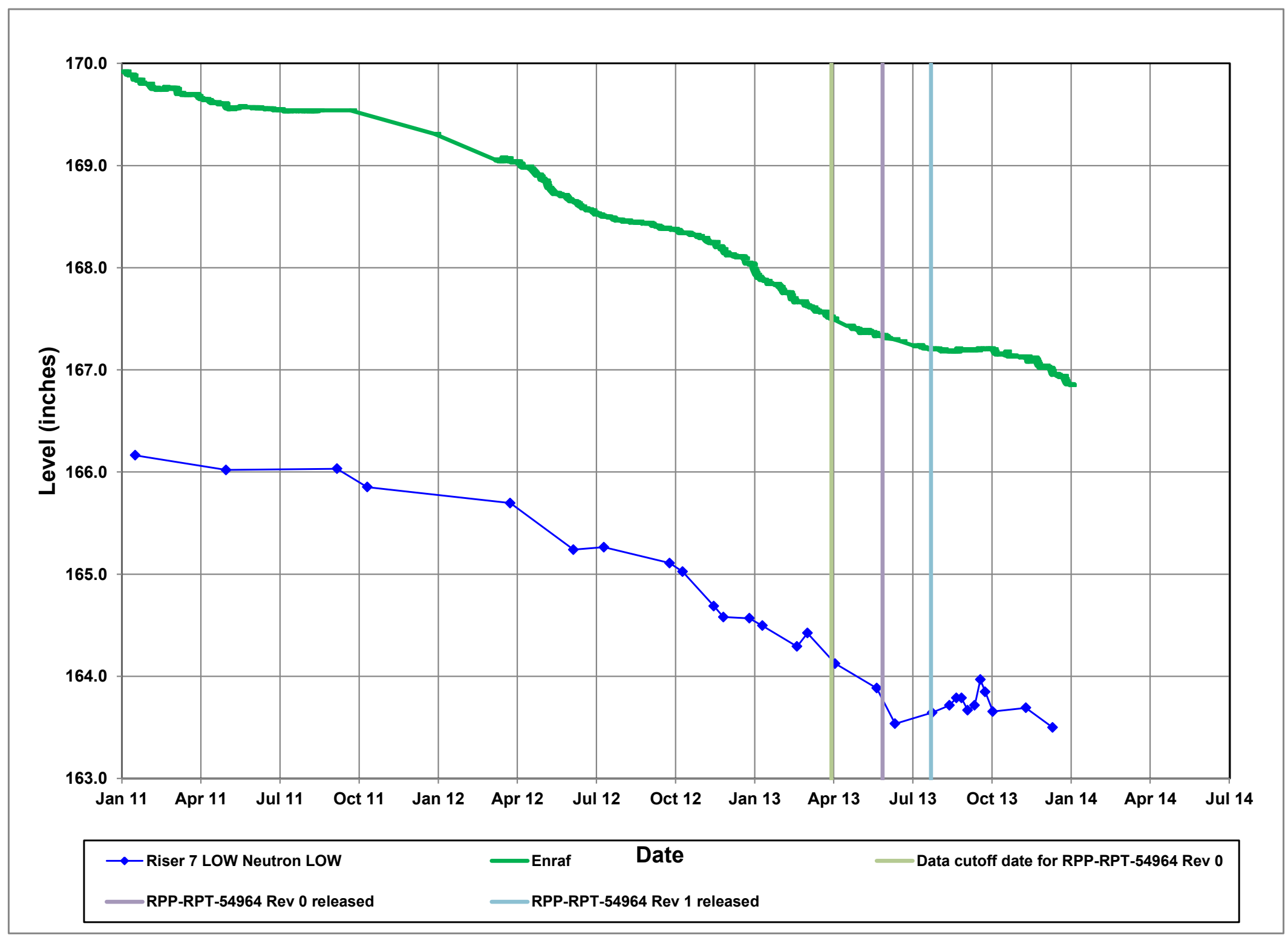


Figure 3 Tank T-111 May 7, 2003 Video Waste Surface Composite

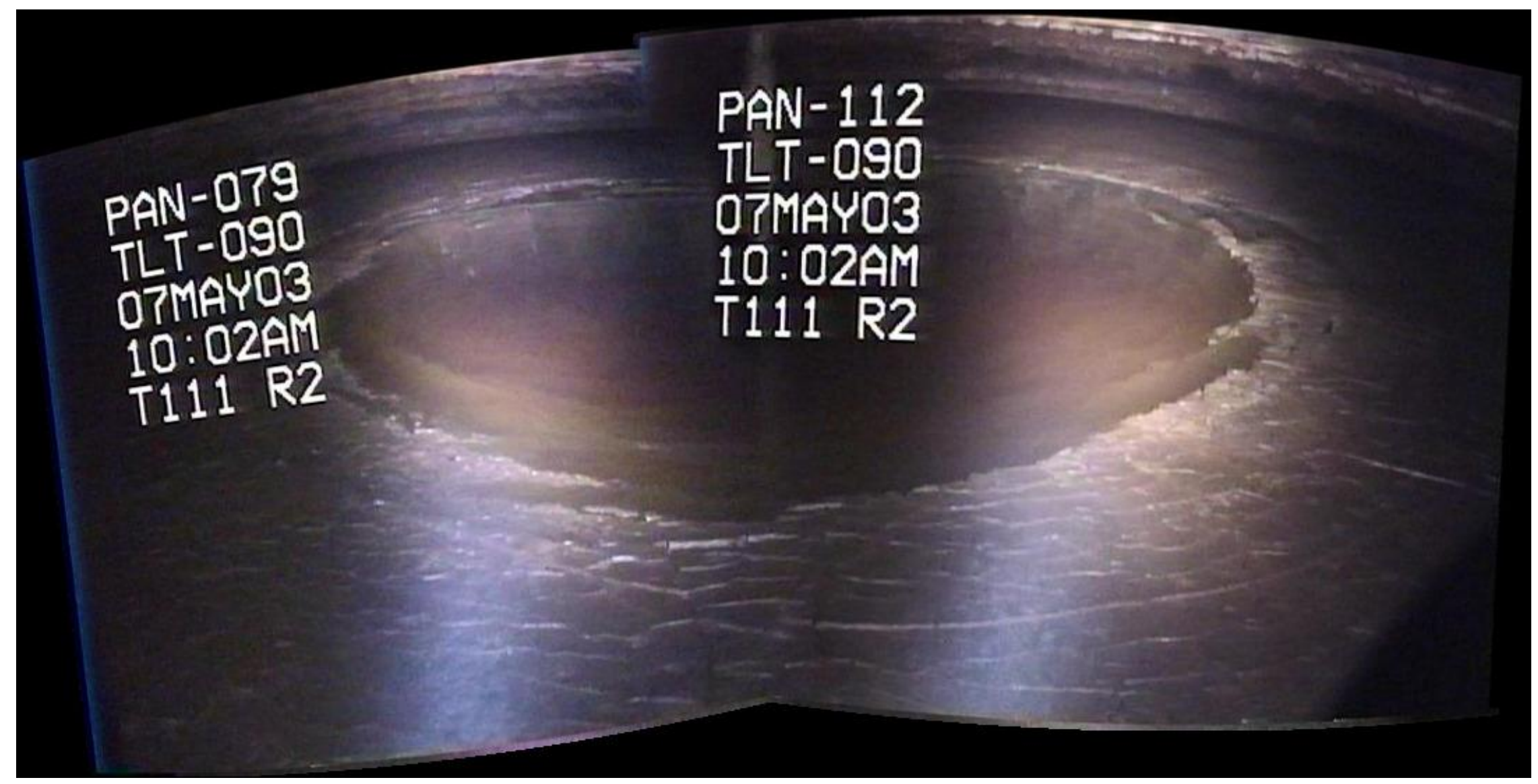


Figure 4 Tank T-111 Enraf Plummet on May 7, 2003

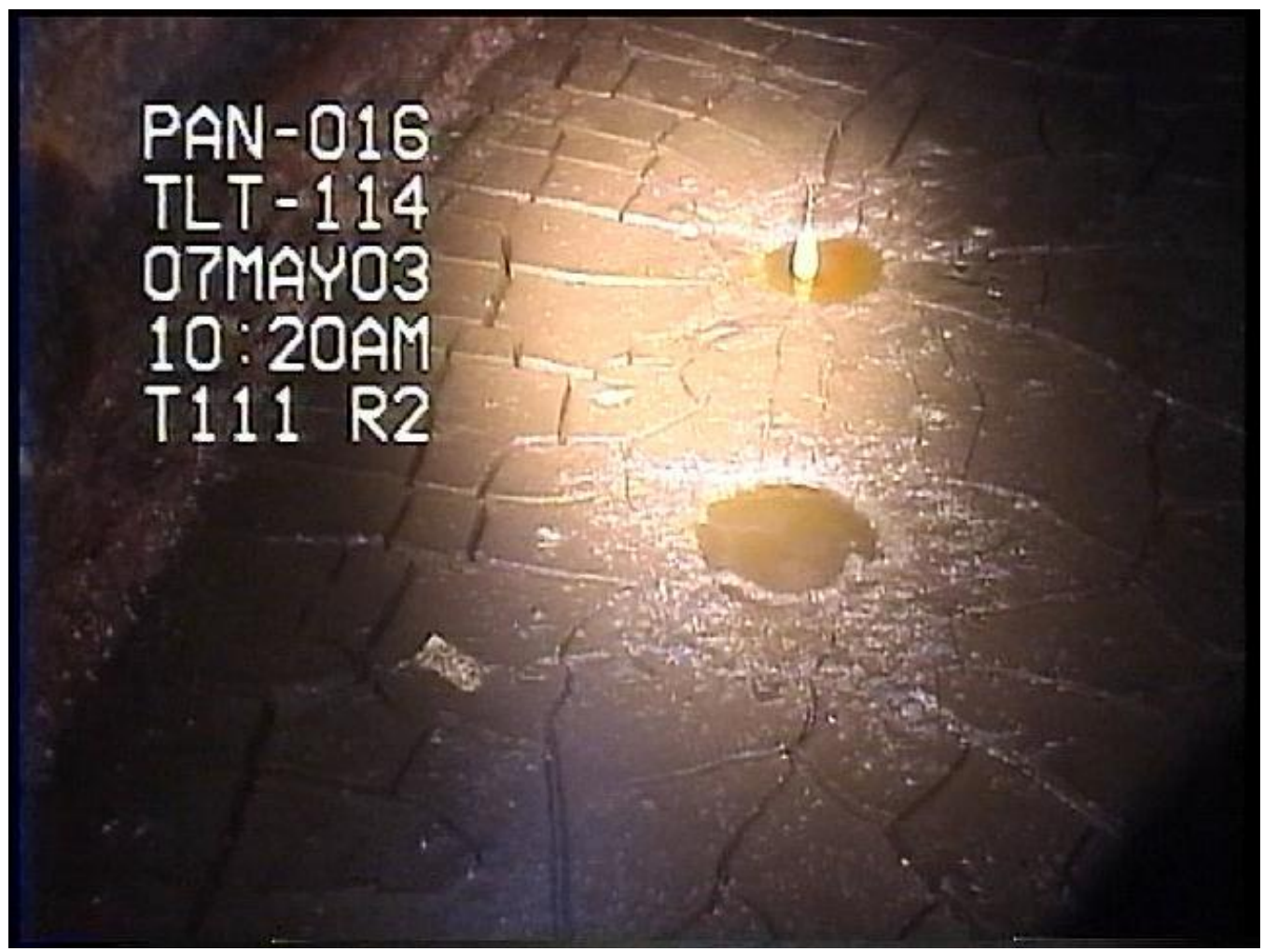

Figure 5 Anomaly on East Wall of Tank T-111 on May 7, 2003

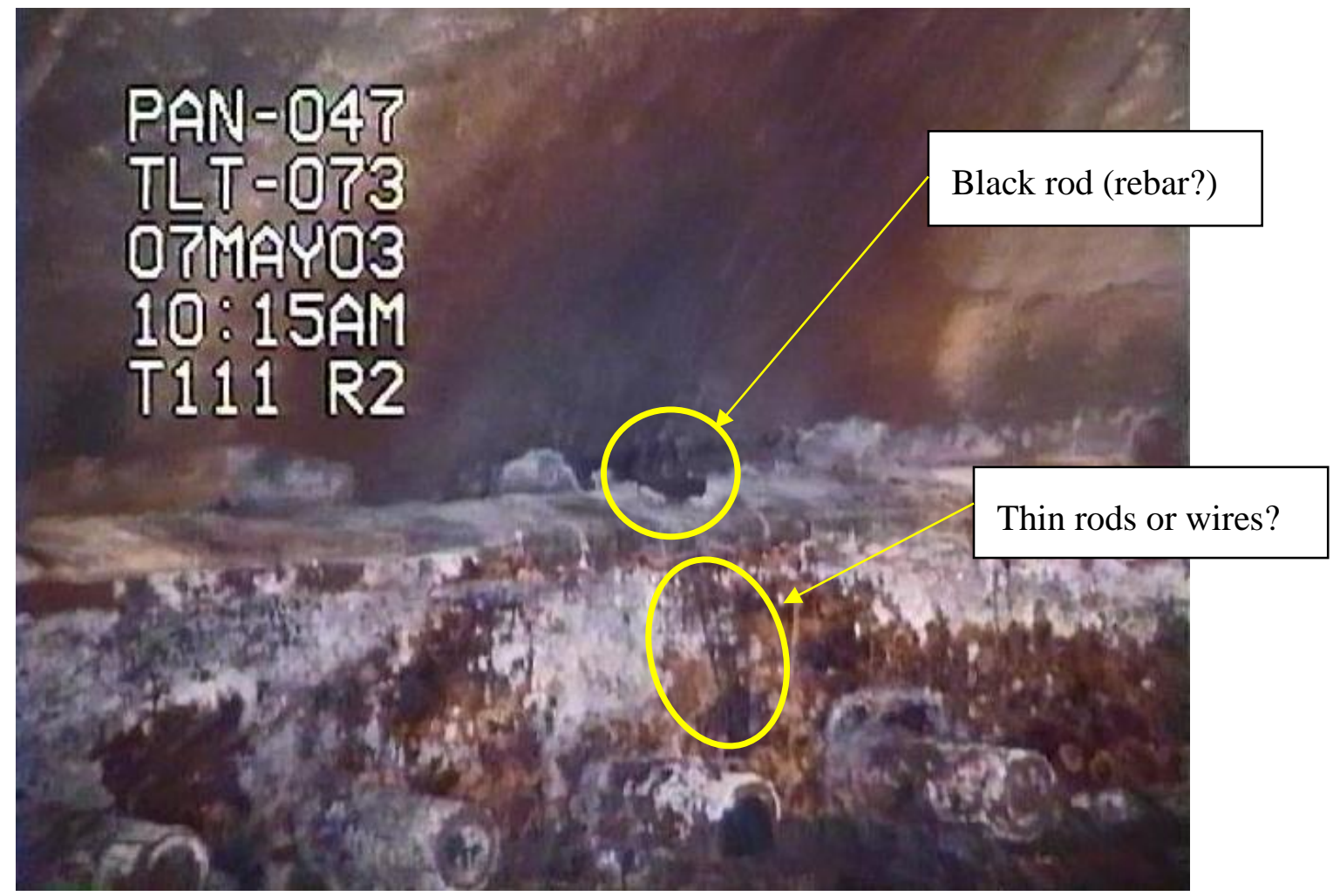




\section{RPP-RPT-54964, Revision 2}

\subsection{February 11 and March 20, 2013 Videos from Riser 6 on Southwest Side of Tank}

Following is a summary of information obtained from the February 11, 2013 and March 20, 2013 tank T-111 in-tank videos.

The central liquid pool is roughly estimated at about $20 \mathrm{ft}$. diameter around the central saltwell screen. Assuming the pool is 6 inches deep the tank T-111 supernatant volume is estimated at about 1,200 gal. The sludge surface is fairly flat with the liquid evident an inch or two below the surface in pools around the LOW and in the tank center. The waste surface appears moist with cracks throughout, similar to the waste appearance in 1994 pre-saltwell pumping photos and the 2003 video.

No active intrusion drips were observed during the February 11 and March 20, 2013 videos, but there was evidence of past intrusion into the tank. Figure 6 shows what appear to be white crystalline 'stalactites' that have formed around the tank circumference on the lip of the lead flashing on the top stiffener ring. There are many of these; all appear to have a white drip line in back of them coming from the edge of the lead flashing where it goes into the concrete wall. The 'stalactites' could be carbonate or sulfate salts similar to what is formed in caves from liquid passing through soil before dripping and evaporating, leaving the crystalline residue behind. These 'stalactites' could also be run-off from the multiple applications of the magnesium zincfluosilicate wash required to be applied to the dome surface per pages 12-13 of the construction specification (BPF-73550, Specifications for Construction of Composite Storage Tanks Bldg. No. 241, Hanford Engineer Works, Project 9536, January 11, 1944) for the tanks. These drip points are seen in some other SST in-tank videos and are evident in the 1994 tank T-111 photos, but do not appear to be as numerous in the latter as in the February 11 and March 20, 2013 videos.

Figure 7 shows a possible intrusion location in the dome. Figure 8 is an image of the waste directly below the Figure 7 location that shows minor depressions which could be from drips from the discolored ceiling area. The video also shows a stain from the Figure 7 location going down the tank dome to the lead flashing above the top stiffener ring.

Figure 9 is the same anomaly shown in Figure 5 located on the southeast area of the dome just above the flashing. The area is black, unlike other dome areas. There appear to be thin black wires directly underneath the anomaly, and there appears to be a greater accumulation of salts under the anomaly than elsewhere along the lip. At full zoom the camera image was too vague to make out clearly what could have caused the discoloration. See Section 3.3 for a later description of the anomaly and better images.

During the initial review of the February 2013 videos there was insufficient time spent looking at the waste liquid pool surface up close to see ripples in the surface. When reviewing the February video again following the December 2013 videos, at the 10:49 time stamp on the video when the camera was only looking at the dome, reflections of ripples were visible on the tank dome. There were at least three different moving ripple reflections, originating from different locations on the pool surface. These ripple reflections were not noticed during the initial video review. Figure 10 shows the reflections from one of the likely ripples. The clarity in Figure 10 is poor, but the reflections are noticeable on the video and are believed to be from drops falling onto the pool surface. The lines are not believed to be shadows from the protective covering around the light used for the video due to their orientation and movement across the dome surface. 
Figure 6 Typical Stalactite on Tank T-111 Top Stiffener Ring Flashing

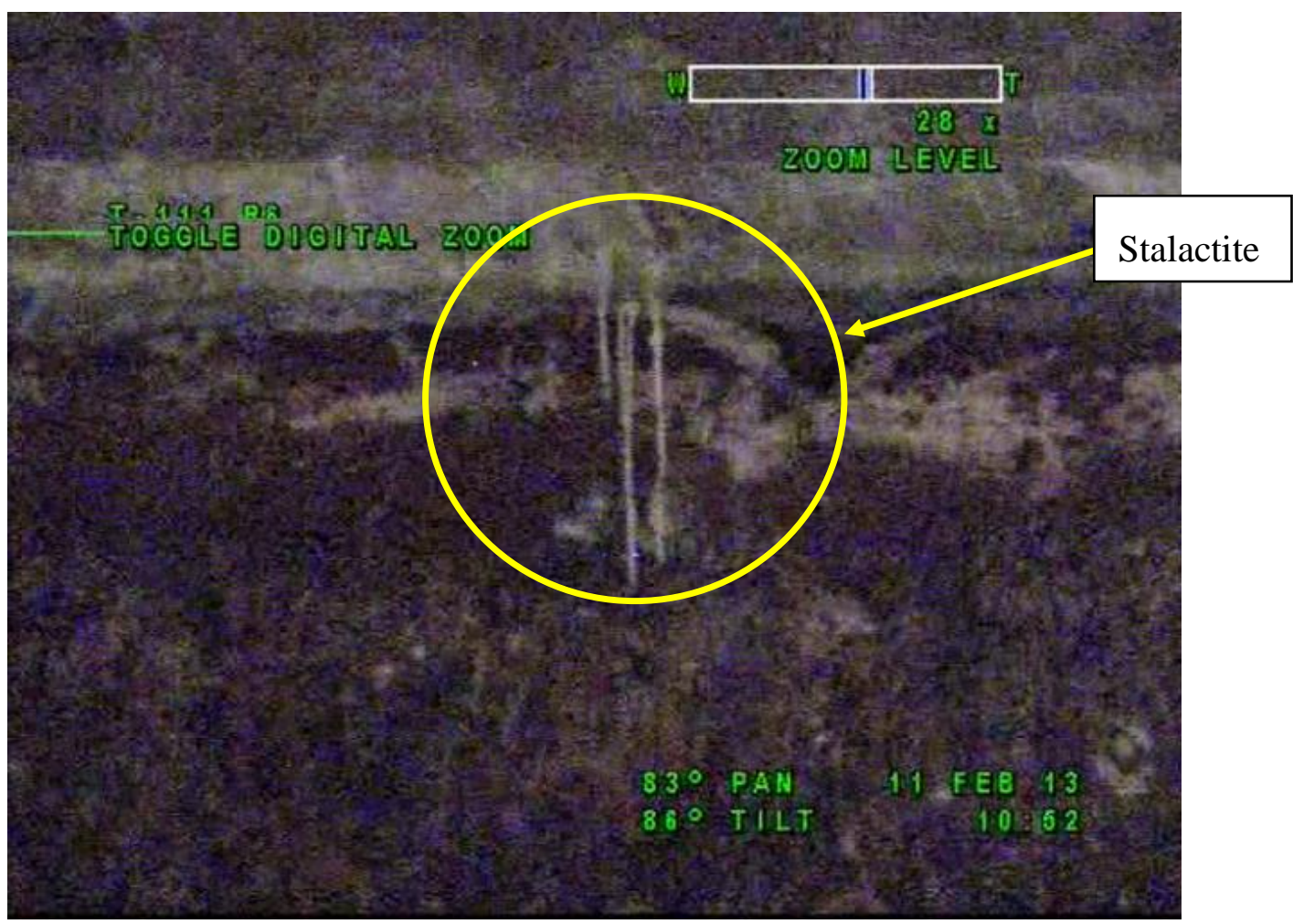

Figure 7 Possible Past Intrusion Location in Tank T-111 Dome

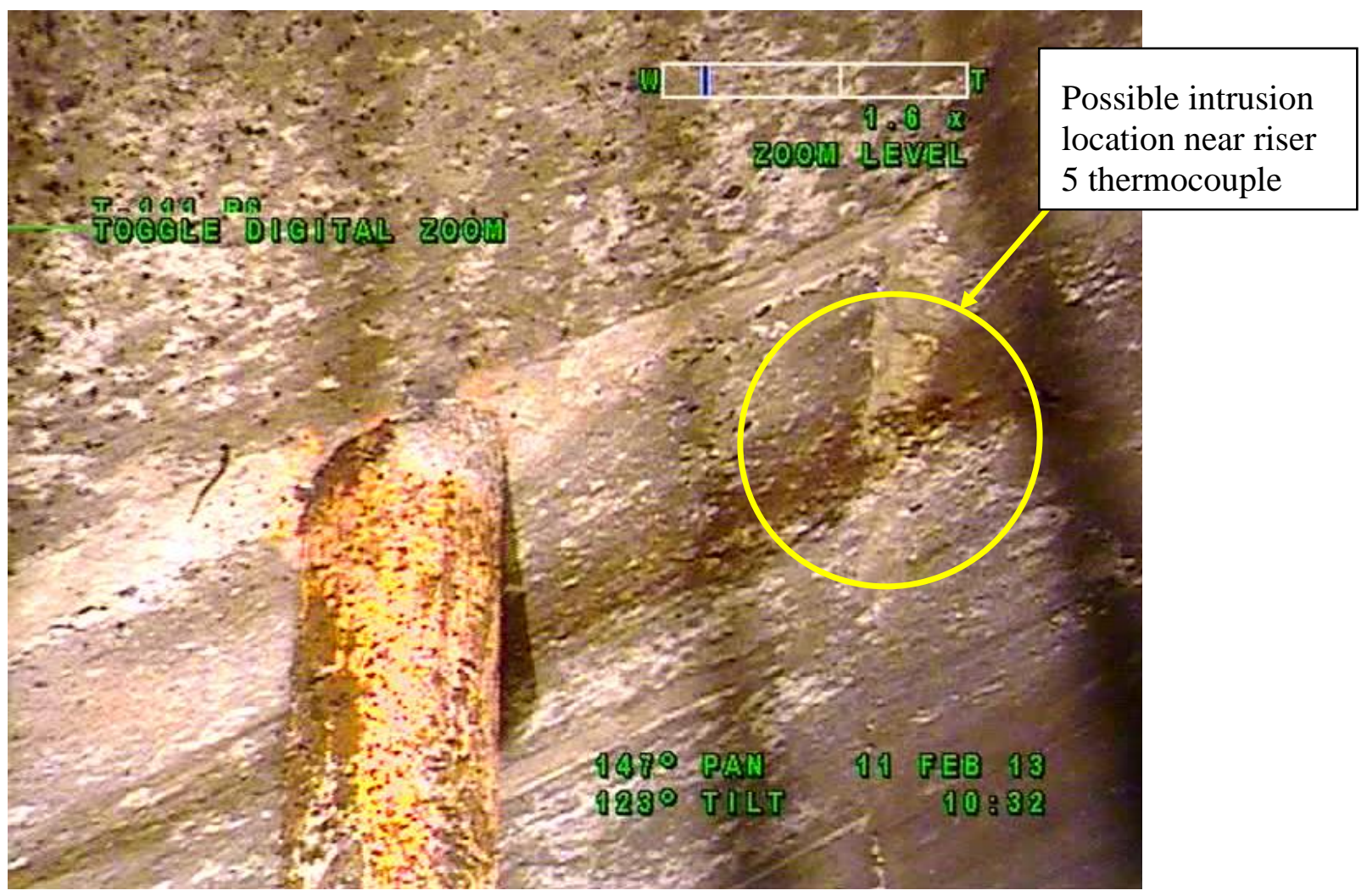


Figure 8 Moist Depressions Directly Below Dome Stain in Figure 8

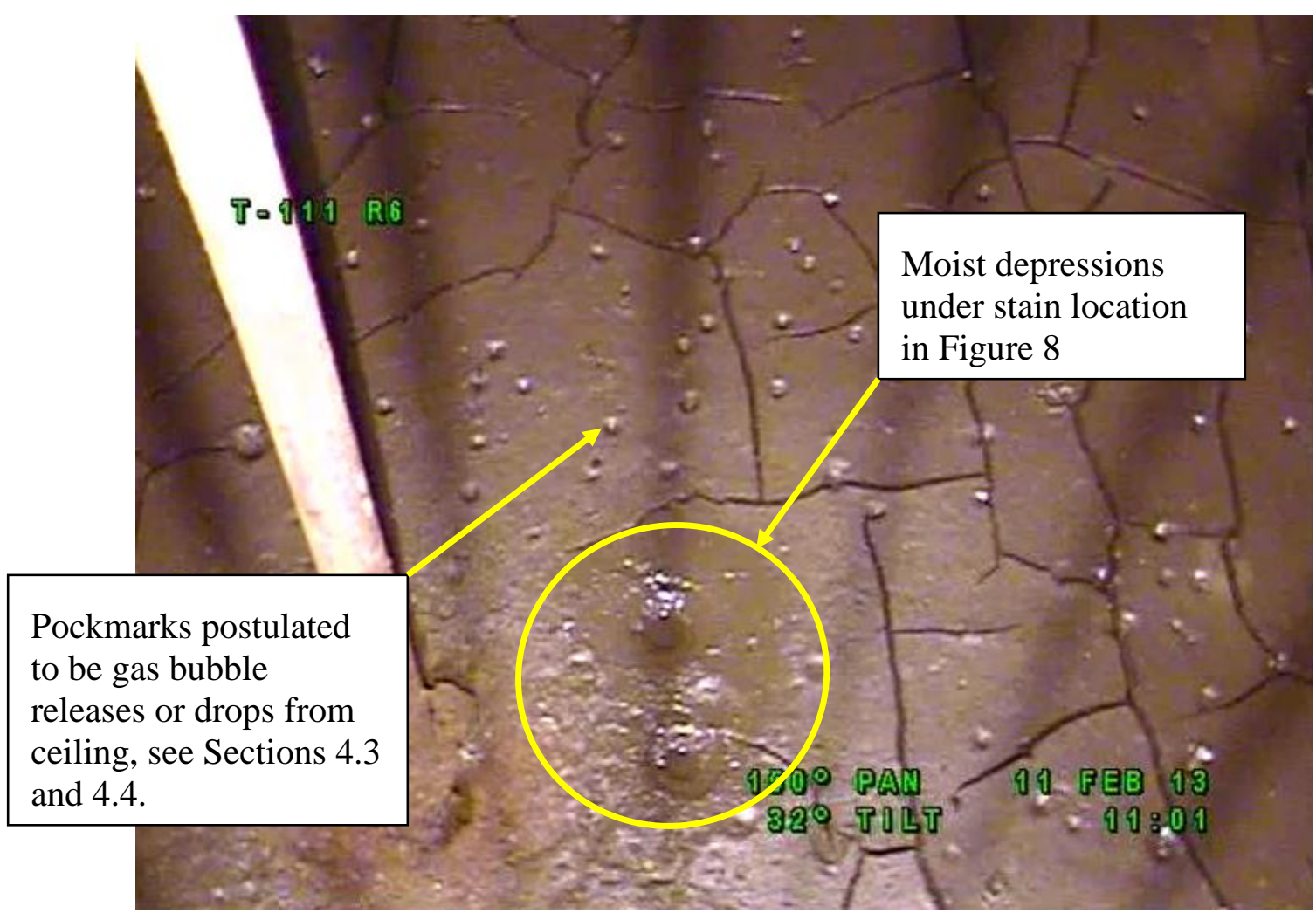

Figure 9 Anomaly on SE Area of Tank T-111 Dome Just Above Top Stiffener Ring

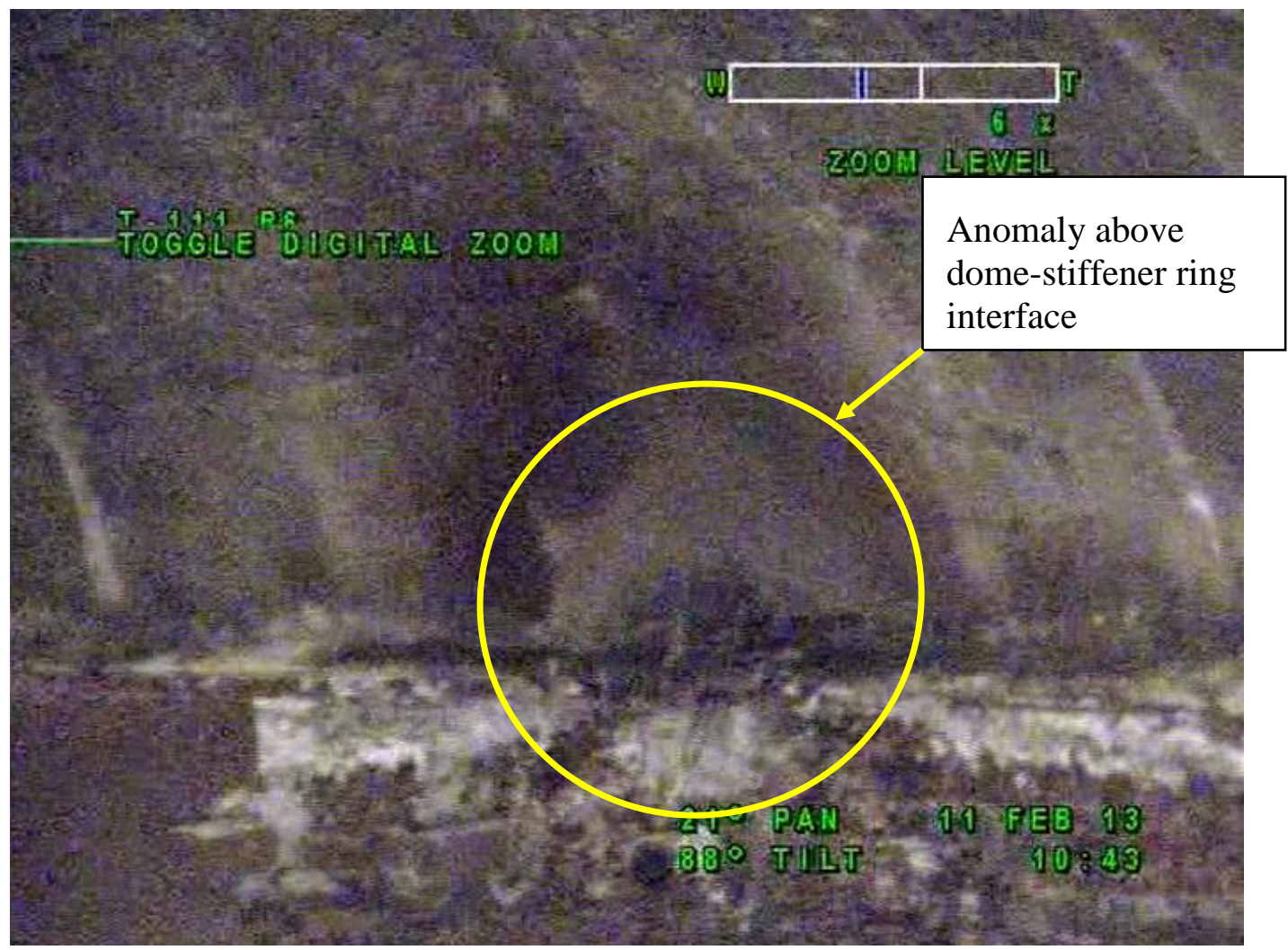




\section{Figure 10 Reflections of Drip Ripples from Pool onto Tank T-111 Dome}

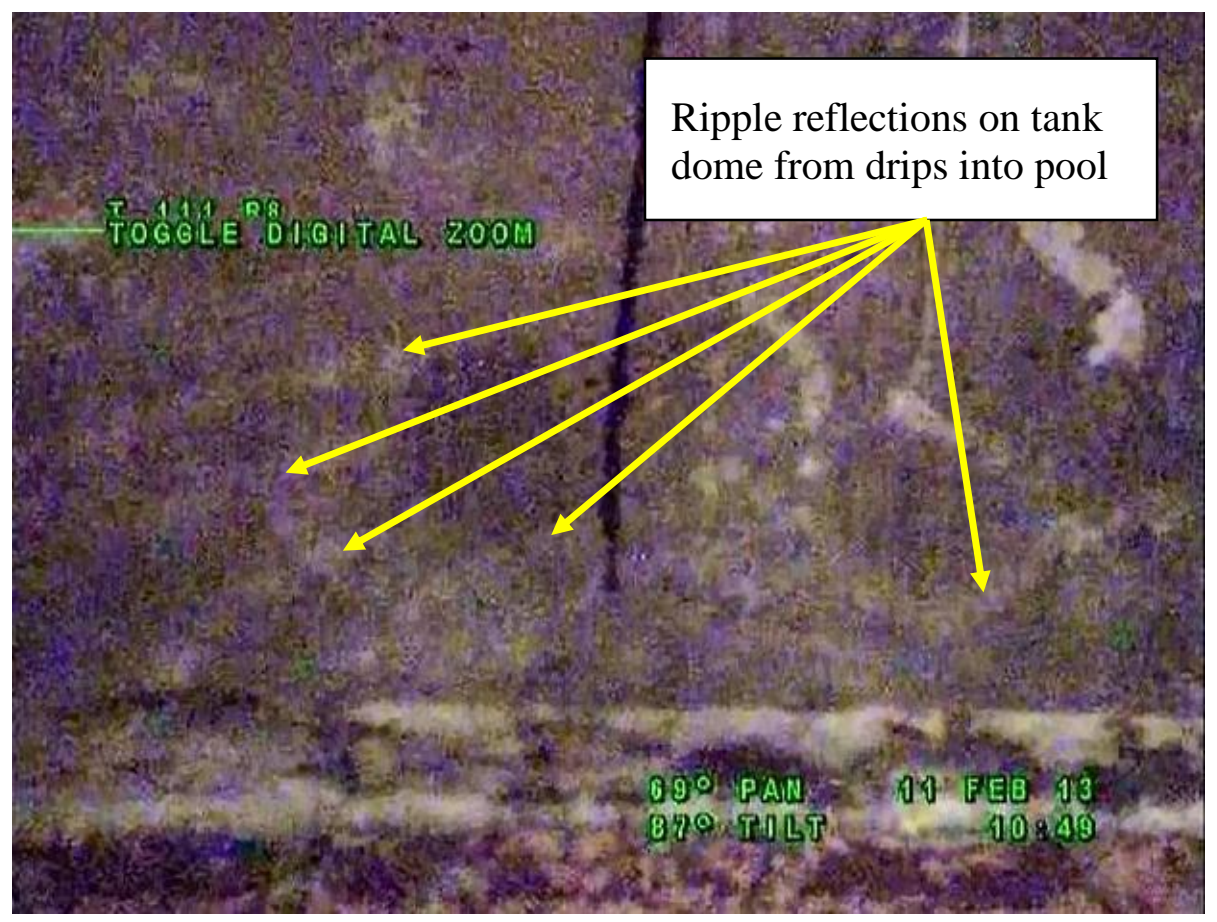

Figure 11 is a screenshot of the tank T-111 central dome area. The white spots are believed to be water droplets. During the initial review of the February 2013 video these spots were assumed to be small bits of salt or something reflective that couldn't be clearly seen with the camera. In the December 2013 videos (see Figure 17 and Figure 18) more of these spots were observed and most of them determined to be water droplets.

Based upon the reflections on the dome ceiling believed to be from water drops falling into the central pool and the probable water droplets observed on the tank dome it appears there was an intrusion occurring during the February 2013 video that was not noted at that time. 
Figure 11 Tank T-111 Central Dome Area Showing Probable Water Droplets

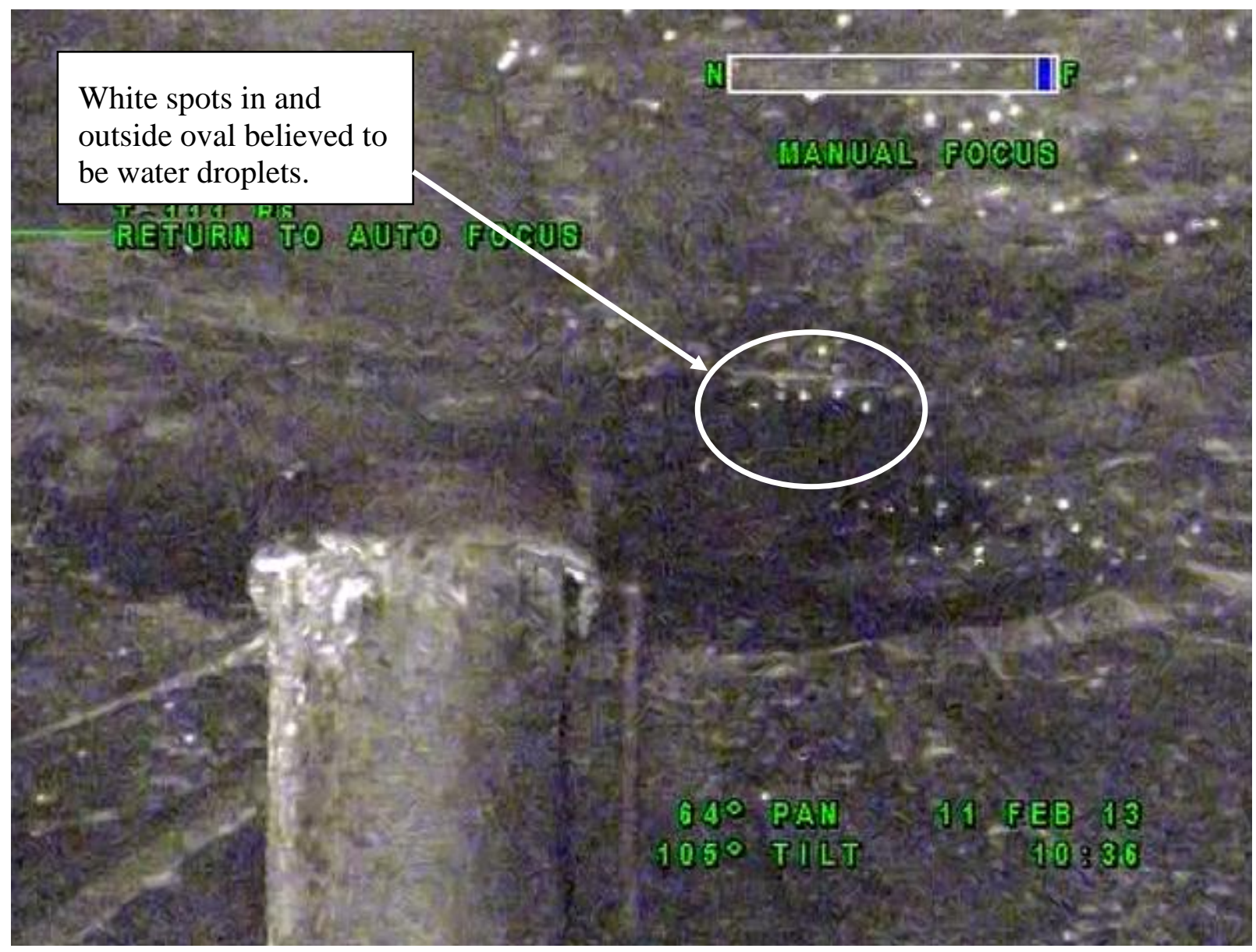

\subsection{December 30 and 31, 2013 Videos from Riser 2 on Northeast Side of Tank}

A video was performed again in December 2013 to try and ascertain what the anomaly was on the east wall of the tank (shown in Figure 5 and Figure 9) and to try and determine if an intrusion was the reason for the change in the tank liquid level since the summer.

Figure 12 shows the Enraf plummet. Note the lesser liquid underneath it when compared to Figure 4 taken ten years earlier. Figure 13 is a screenshot of the plummet including the area under adjacent riser 3. The decreased liquid under riser 3 in comparison to Figure 4 is apparent.

Figure 14, Figure 15, and Figure 16 are close-ups of the anomaly on the east wall of the tank. It appears the anomaly may be some sort of minor wall repair made at the time the tank was constructed. The strips with the apparent stripes on each edge look like thin metallic strips or tape, although tape usage would be unlikely in 1943. Comparing Figure 4 with Figure 16 it appears the strips were more wrapped under the lead flashing on the top stiffener ring in 2003 than in 2013. The white salts under the anomaly appear more prevalent than in other areas around the flashing in the tank, which implies there may be an intrusion of liquid from the soil around the tank at this location, but the amount of salt present probably doesn't indicate a significant intrusion. 
Figure 12 Tank T-111 Enraf Plummet, December 31, 2013

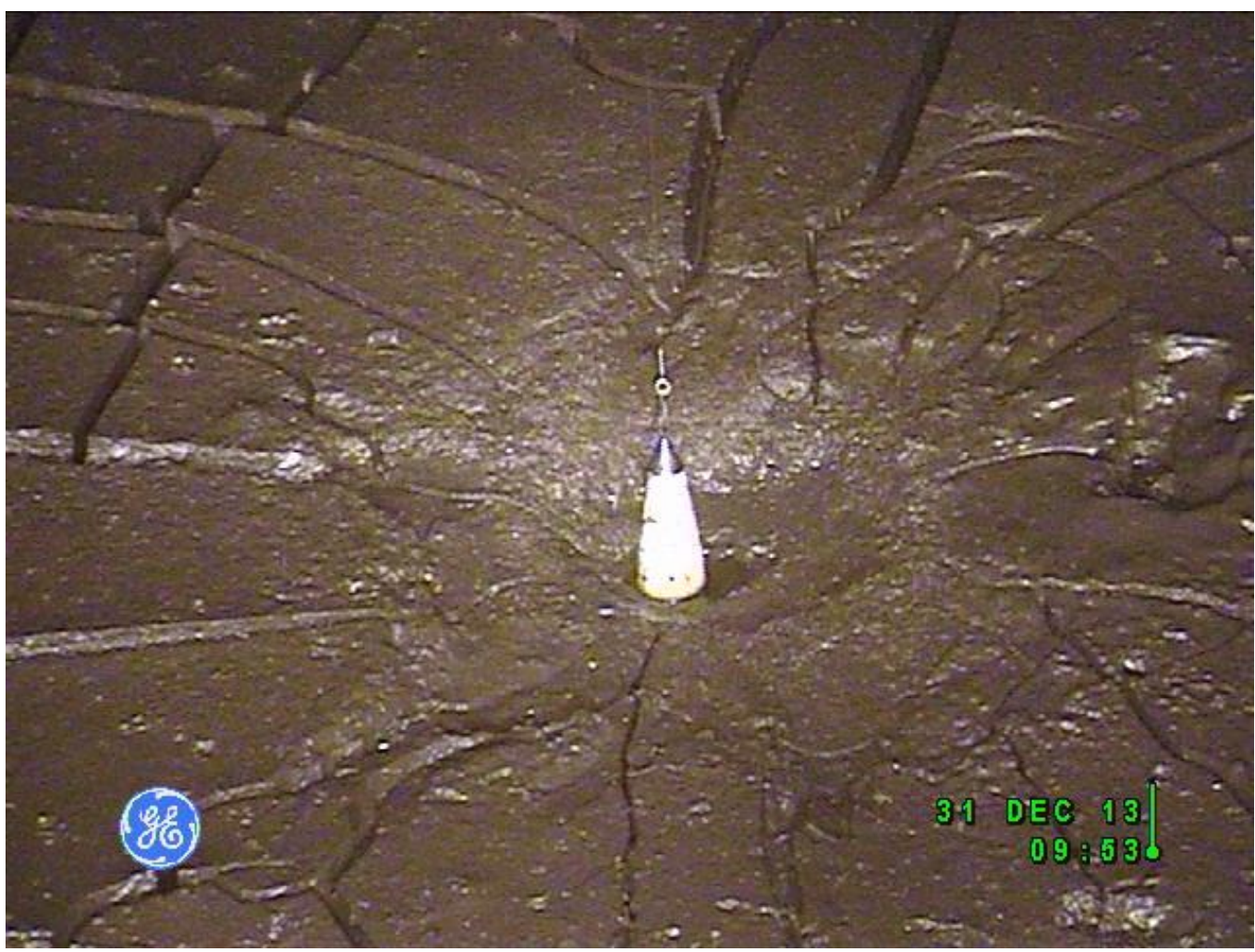

Figure 13 Tank T-111 Enraf Plummet and Area Under Riser 3, December 31, 2013

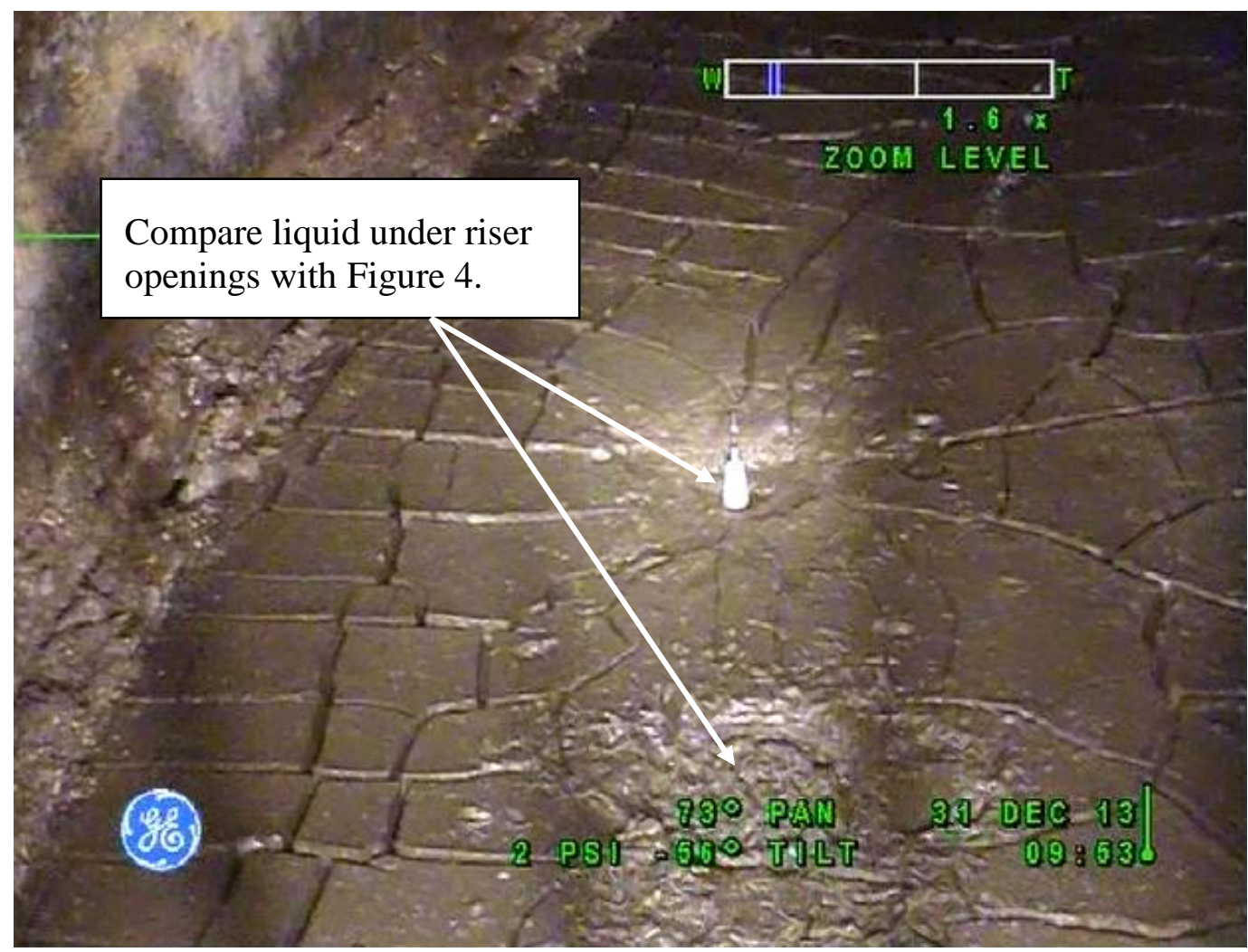


Figure 14 Closeup \#1 of Anomaly on Tank T-111 East Wall, December 31, 2013

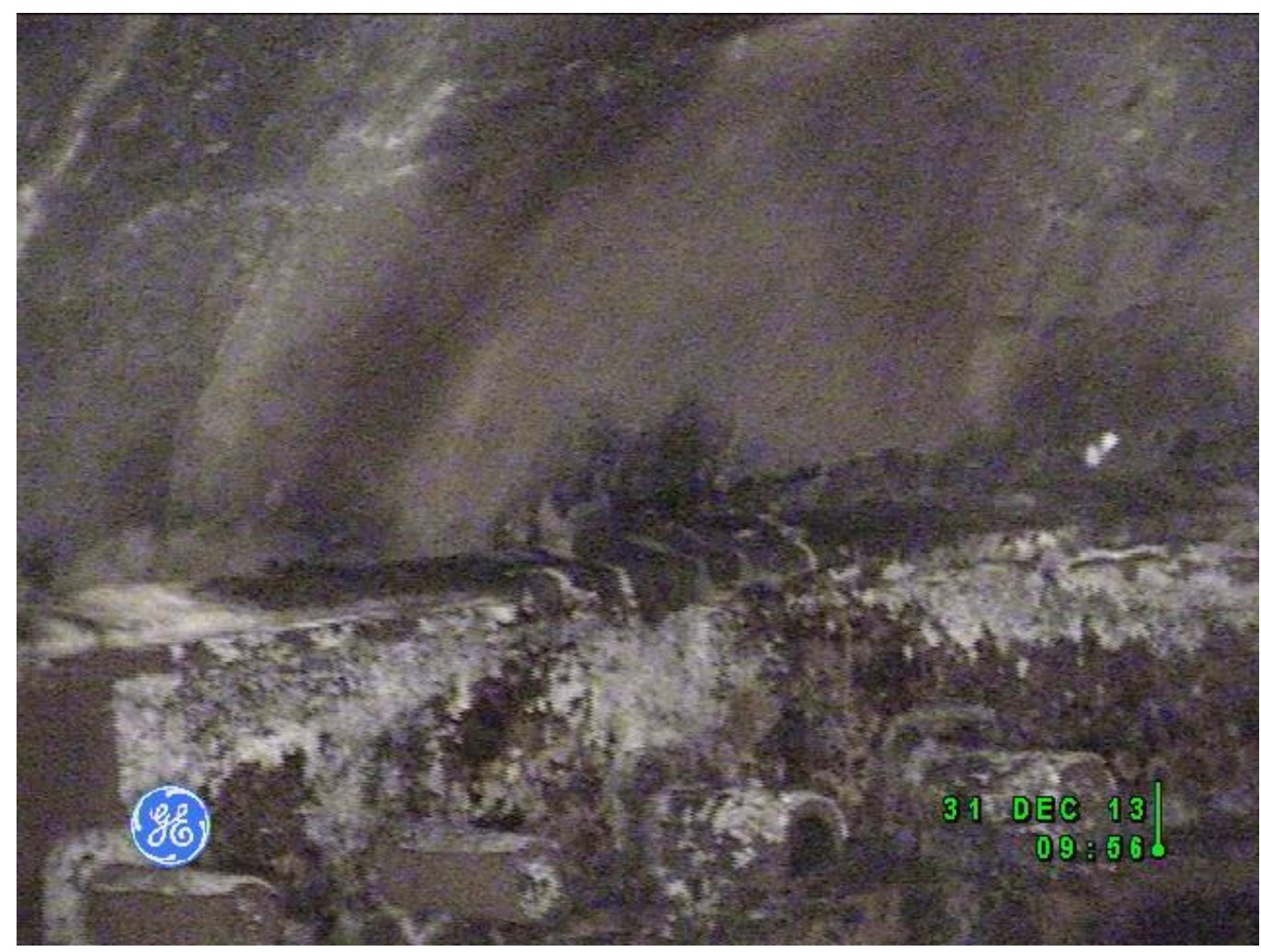

Figure 15 Closeup \#2 of Anomaly on Tank T-111 East Wall, December 31, 2013

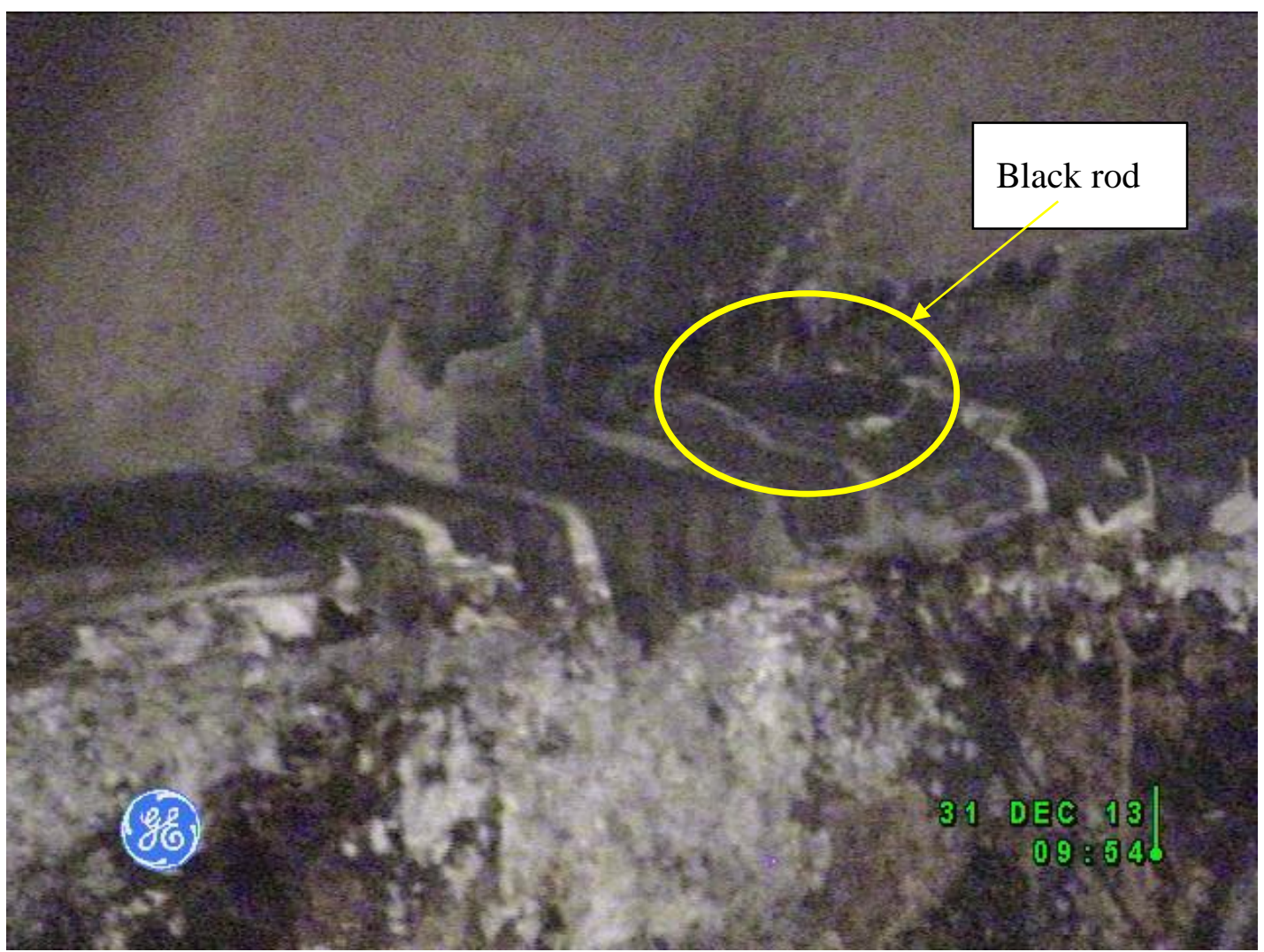


Figure 16 Closeup \#3 of Anomaly on Tank T-111 East Wall, December 31, 2013

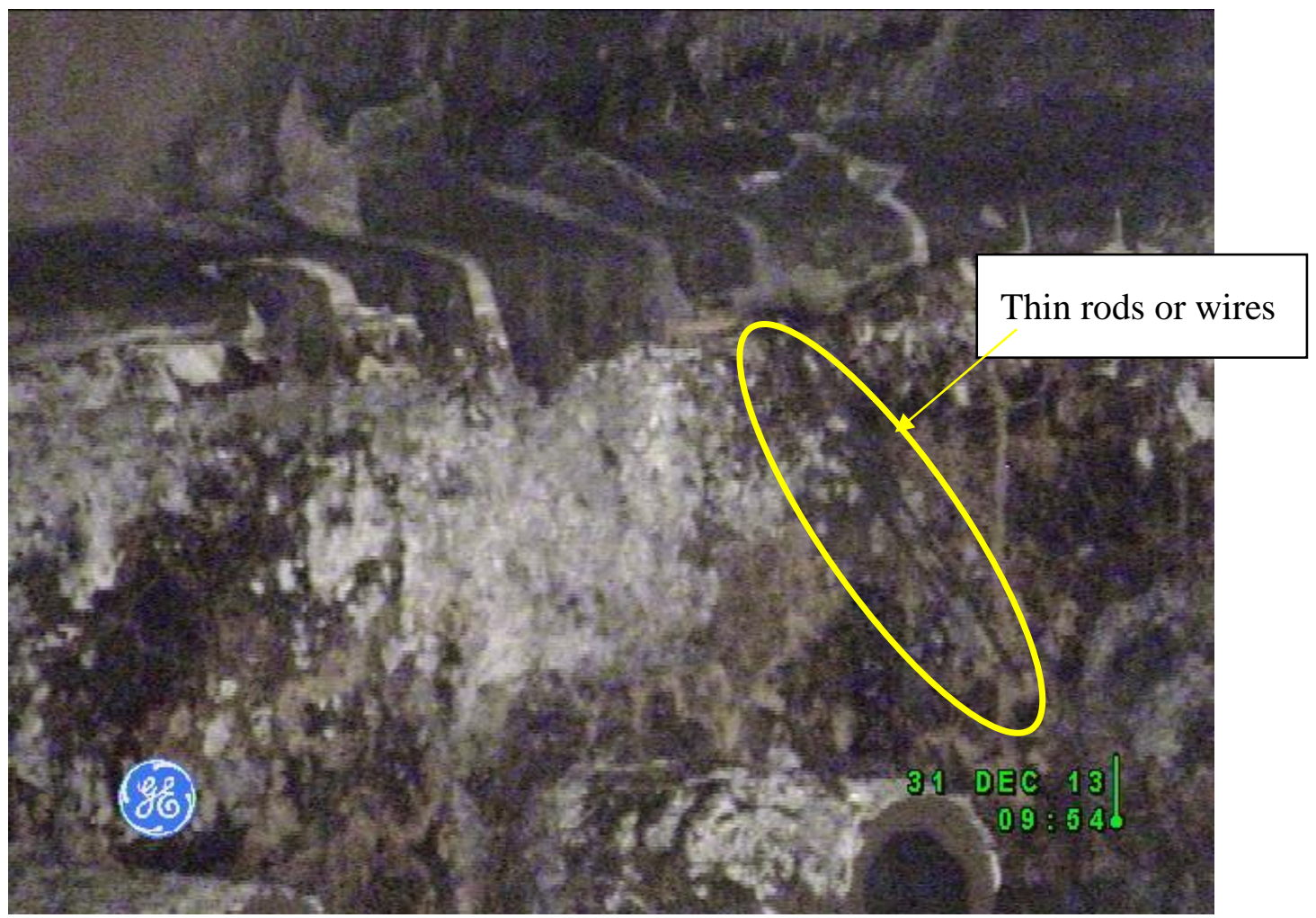

Intrusion from the central dome area of the tank was observed on both December 30 and

December 31, 2013. Ripples were observed on the central pool surface from drops. The ripples are difficult to see in the stills but are readily apparent in the video.

Figure 17 is an image from December 30 showing the central dome area of the tank. Note the small reflective white spots. Camera resolution did not enable clear viewing of these spots, but at least one of them was a water droplet. Figure 18 shows two close-up views of an area on the tank dome. In the first view five of the reflective spots are present in the circled area. In the second view only four are present. On the video the drop can be clearly seen to fall, it wasn't practical to get an image of it at the exact instant the drop fell.

The similar reflective nature of the white spots implies they are all water droplets. The area of the white spots roughly corresponds to the area of the central pool in the tank where most of the ripples were noted.

It is impractical to get a good count rate for the water drops from the ceiling because of their random distribution, but by observing different areas of the pool for a period of time and adding the ripples seen in different areas of the pool the drip rate was estimated to be in the range of eight to nine drips per minute. See Section 4.4 for a volumetric estimate of the intrusion rate.

A possible explanation for the ceiling droplets is they are condensate formed when liquid from the central pool evaporates and condenses on a cooler tank dome. The last winter temperature data available (February 2013) shows the waste temperature about $64^{\circ} \mathrm{F}$ and the upper headspace air about $60^{\circ} \mathrm{F}$. The tank dome should be the same temperature as the soil, about $60^{\circ} \mathrm{F}$ since it is approximately eight feet below grade. Condensation cannot be ruled out, but is not likely, and similar drops have not been seen in other SSTs to date with liquid present. 
Figure 17 Tank T-111 Showing Water Droplets on Central Dome Area, December 30, 2013

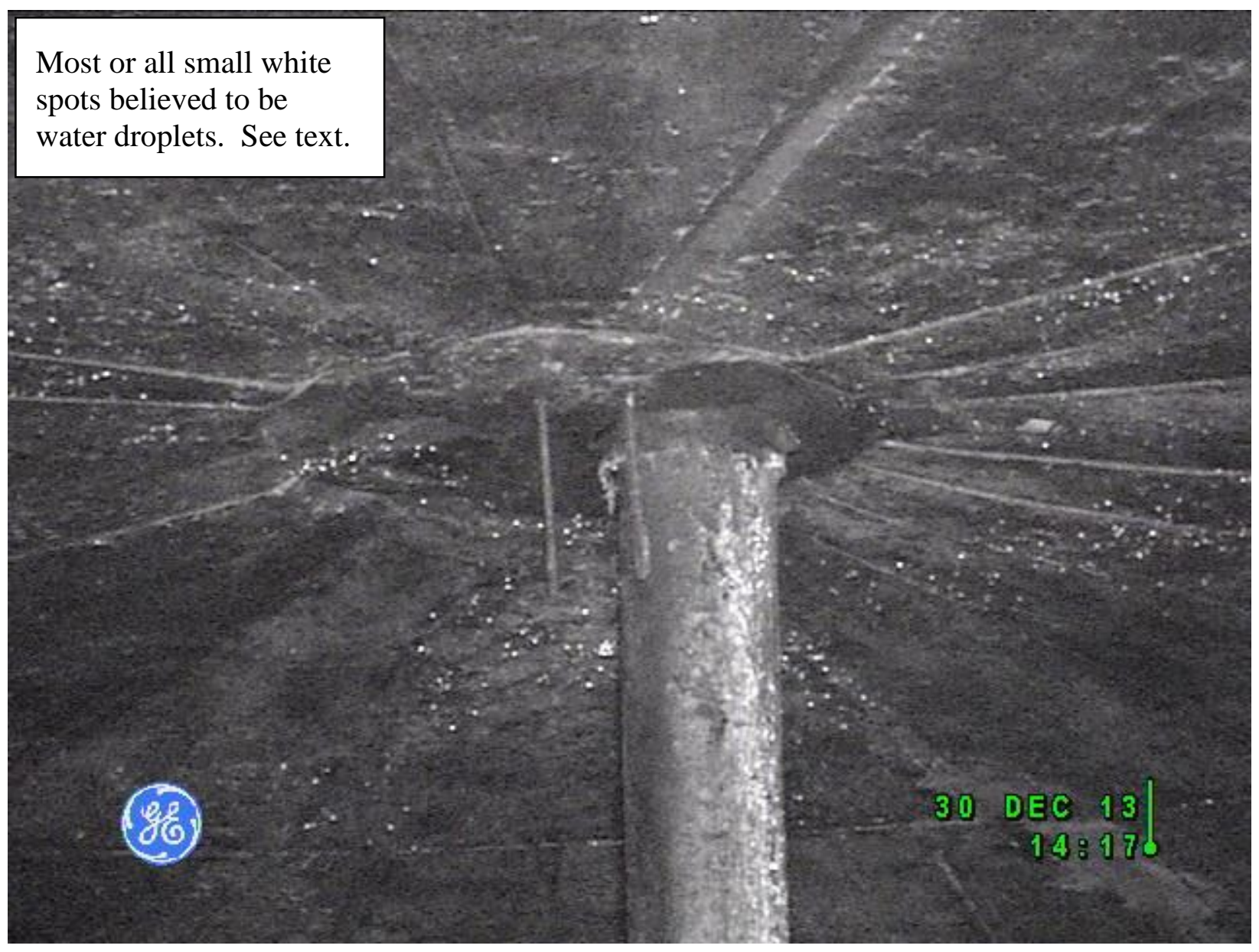

The 2003 video was reviewed to look for water droplets on the dome at that time. The review was inconclusive. No droplets were noted, but there were no closeup video images of the central dome area either. One 2003 view from a considerably wider angle than either Figure 11 or Figure 17 showed what might have been water droplets in a more sparse pattern than in either of these two figures, but it cannot be stated from the 2003 video that water droplets were or were not present in the central area of the tank T-111 dome.

Figure 19 shows a panorama of the tank T-111 waste surface. 
RPP-RPT-54964, Revision 2

Figure 18 Water Drop from Tank T-111 Dome
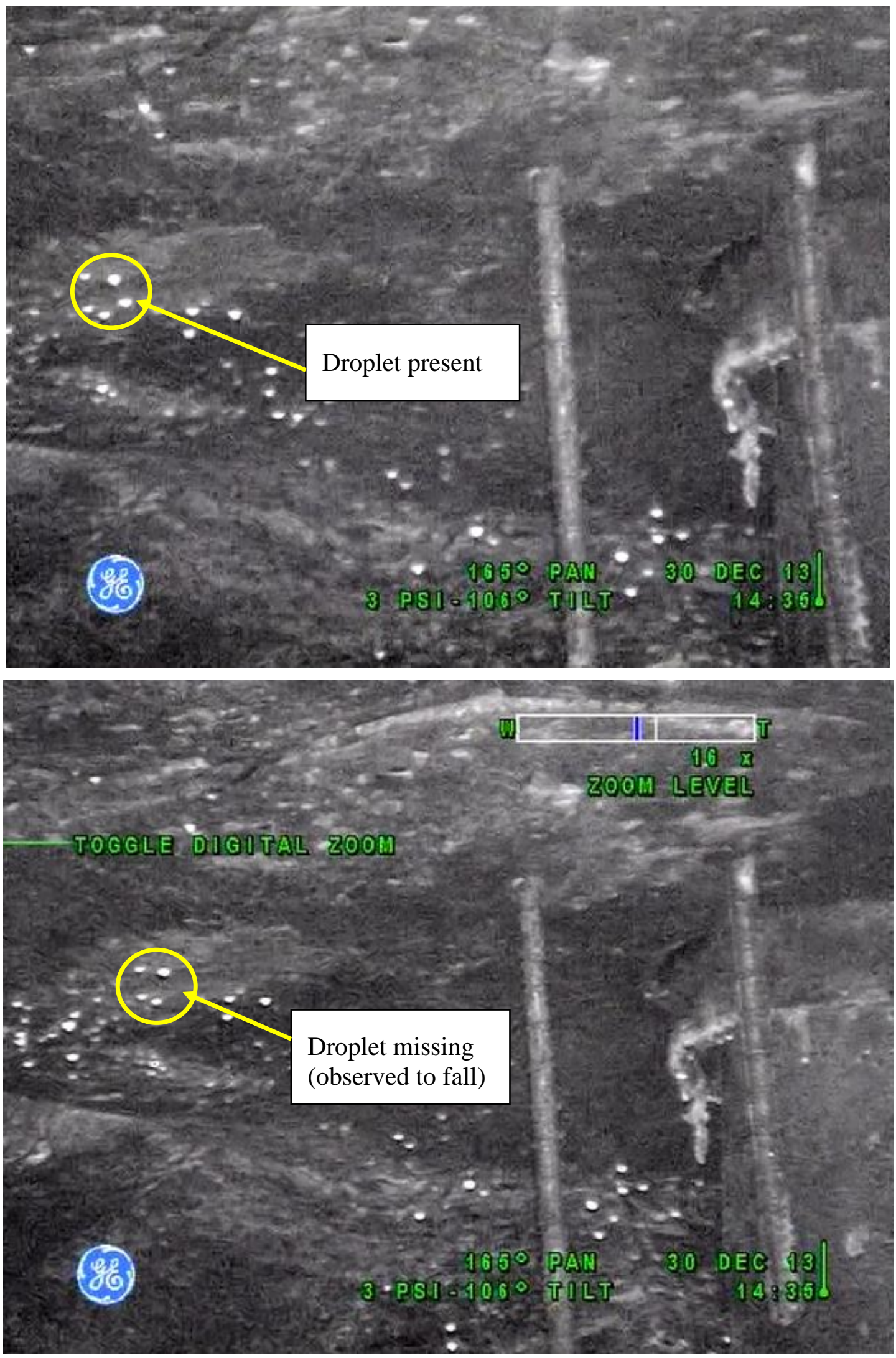
RPP-RPT-54964, Revision 2

Figure 19 Tank T-111 Waste Surface Panorama from December 31, 2013

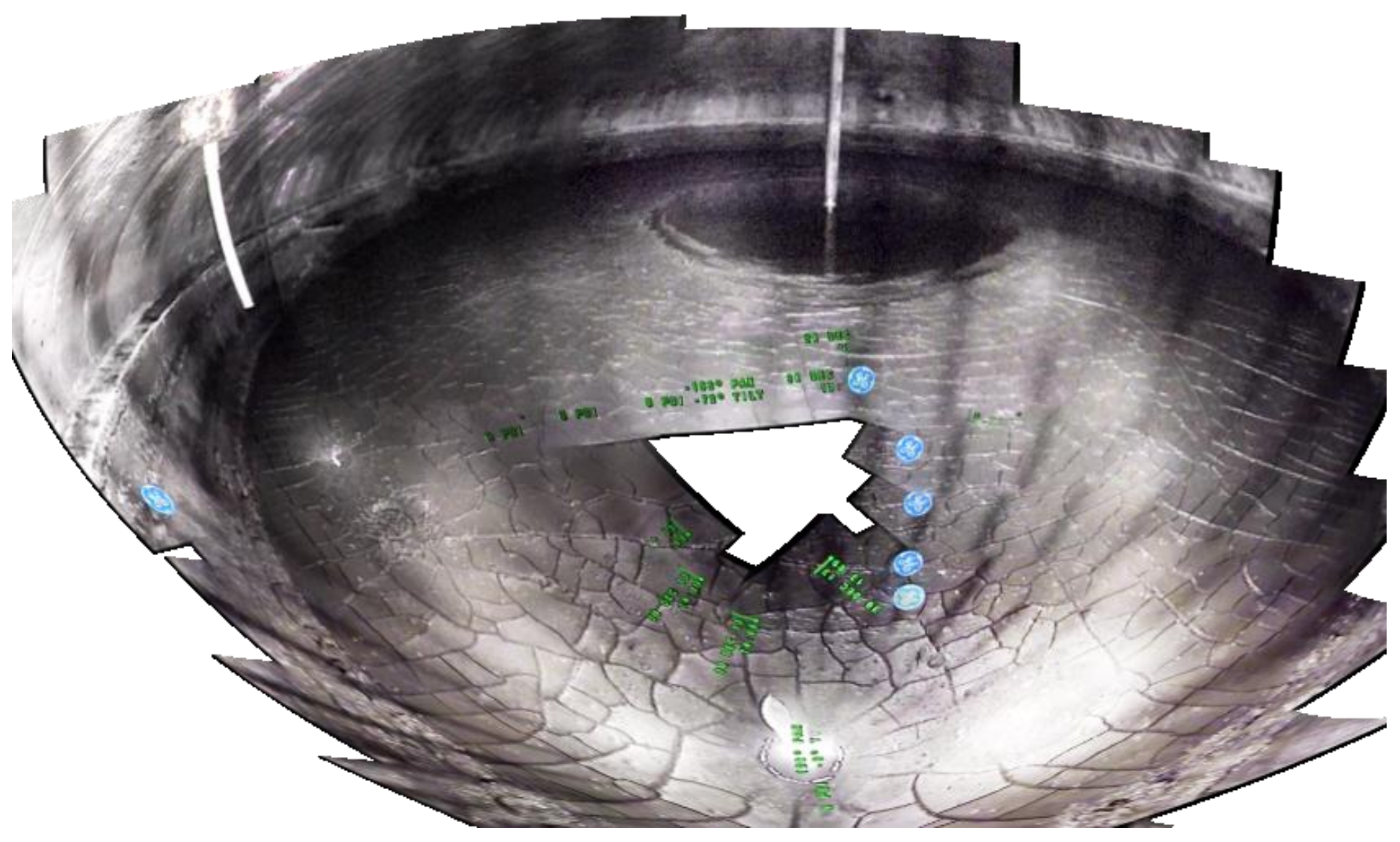


RPP-RPT-54964, Revision 2

\subsection{Evaluation of Tank T-111 Liquid Level Data Changes}

Tank T-111 levels prior to December 1972 were calculated from reported waste volumes. Most if not all of the SL data between December 31, 1972 and July 13, 1995 were obtained using a Food Instrument Corporation (FIC) gauge, with some of the 1970s data possibly being obtained with a manual tape. When the Enraf gauge was installed in July 1995 the first reading was only 0.13 inches lower than the last FIC gauge reading.

The LOW, installed in 1985, and the Enraf surface level gauge are on opposite sides of the tank from each other but the ILL and SL data for tank T-111 track each other closely. This infers the ILL is stabilized throughout the tank waste. From videos taken on May 7, 2003,

February 11, 2013, and December 31, 2013 the Enraf plummet is sitting in a small depression and appears to be reading the ILL. Based upon the last video there is not much liquid left around the plummet.

Estimated tank T-111 leak rates and a post-1994 tank T-111 leak volume are derived by:

1. Estimating SL and ILL change rates for most time periods from 1973 on, excluding active pumping periods or when the ILL had not yet stabilized.

2. Plotting SL and ILL change rates vs. time.

3. Deriving a post-1994 tank liquid level change rate plot and formula.

4. Correlating the liquid level change rate to a volumetric change rate.

5. Data analysis and adjustment.

6. Estimating an evaporation rate.

7. Estimating a volumetric intrusion rate.

8. Estimating a volumetric leak rate from the volume change rate after adjusting for the impacts of data analysis, evaporation, and intrusion.

9. Estimating a leak volume from the volumetric leak rate and the time.

\subsection{Tank T-111 Level Change Rate}

The tank T-111 level change rates were estimated separately for the time up to June 13, 2013 and the time after June 13, 2013. June 13, 2013 was chosen because that is the date of the last ILL reading which showed the negative trend present since 2006.

Surface Level Change Rate from 1973 to 1974 - Tank T-111 was first suspected of leaking due to a level decrease noted in 1974 . Figure 20 plots the data from that period on an expanded $\mathrm{x}$-axis and $\mathrm{y}$-axis and uses Excel to calculate a linear regression line for the decrease. The level change rate in inches per year is equal to 365.25 times the slope of the regression line formula. The decrease rate was $-0.364 \mathrm{in./yr}$.

Note: When using regression line formulas calculated by Excel, care must be taken to ensure a sufficient number of significant digits are included for the coefficients. Excel stores dates on a January 1, 1900 basis, using too few significant figures for the regression line formulas can sometimes produce erroneous predicted waste levels, and thus erroneous volume change rates. 
RPP-RPT-54964, Revision 2

Figure 20 Tank T-111 Initial Level Decrease 1973 - 1974

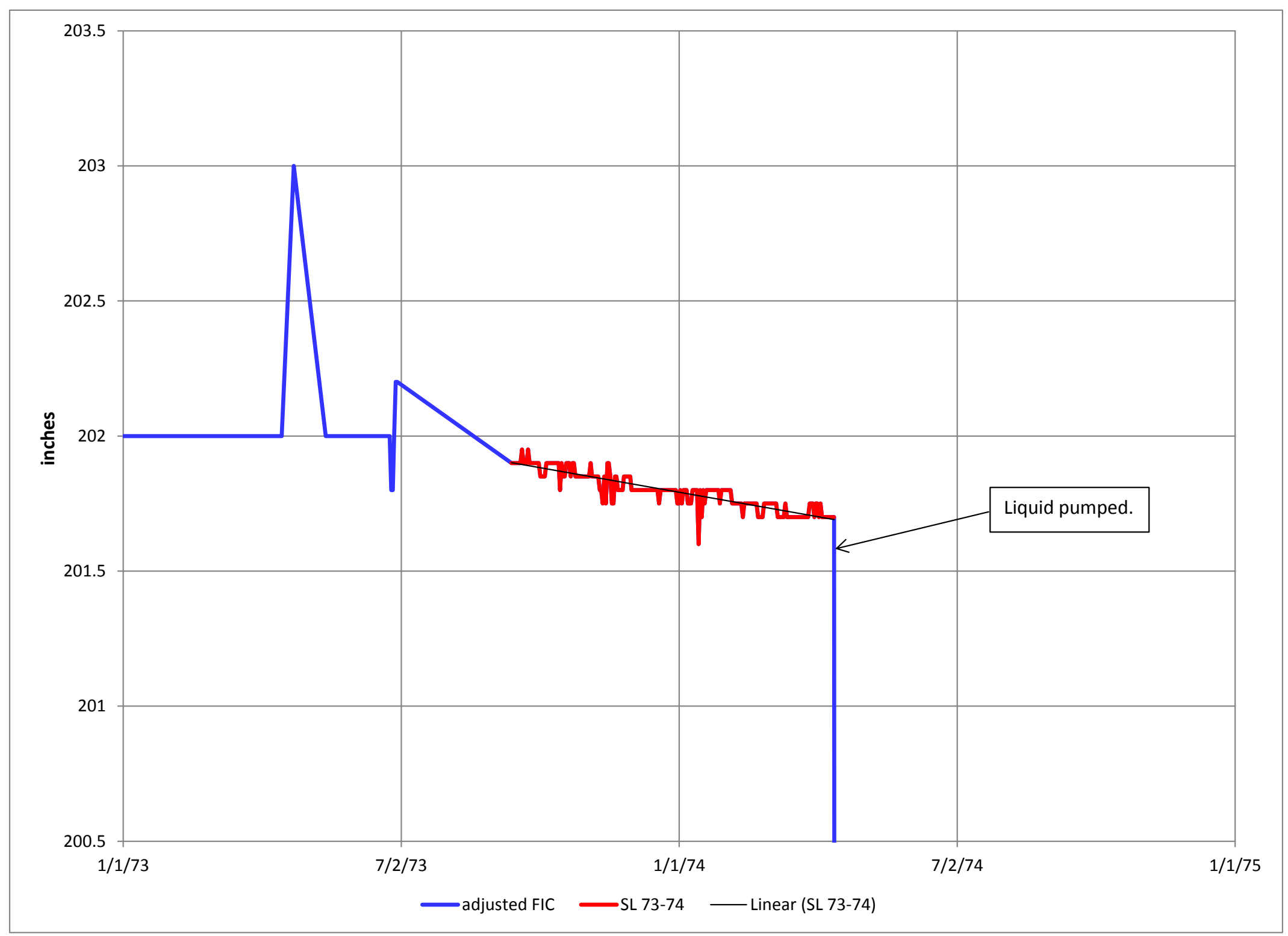


Surface Level and Interstitial Liquid Level Change Rates from March 1979 to June 2013 A date of March 1, 1979 was selected as the beginning date for level change rate estimation following the 1976 to 1978 saltwell turbine pumping since the level decrease appeared to be stabilized and an intrusion was beginning. A cutoff date of June 13, 2013 was selected as an end date because after that date the ILL trend direction changed.

The level data up to June 13, 2013 were divided into separate time periods for calculation of liquid level change rates. Figure 21 shows the SL and ILL data with the separate regions identified. The time periods were selected based upon engineering judgment to enable linear change rates to be applied to the extent practical:

1. Period SL 79-89: surface level March 1, 1979 to January 3, 1989, used linear change rate. The spurious $1.75 \mathrm{in}$. data spike during the period was removed.

2. Period SL 89-92: surface level January 3, 1989 to January 22, 1992, used linear change rate.

3. Period SL 92: surface level from February 26, 1992 to June 28, 1992, used zero change rate.

4. Period SL 92-94: surface level from July 6, 1992 to May 15, 1994, with questionable data from November 23, 1992 to January 4, 1993 removed, used polynomial change rate.

5. Period undesignated, May 15, 1994 to July 13, 1995: saltwell jet pumping and surface level equilibration.

6. Period SL 95-99: surface level July 13, 1995 to May 10, 1999, used linear change rate.

7. Period SL 99-13: surface level May 10, 1999 to June 13, 2013, used polynomial change rate.

8. Period ILL 85-92: interstitial liquid level April 12, 1985 to October 22, 1992, used linear change rate.

9. Period ILL 92-94: interstitial liquid level October 22, 1992 to May 12, 1994 (last data point before start of saltwell jet pumping), used linear change rate.

10. Period undesignated, May 19, 1994 to May 14, 1998: saltwell jet pumping and interstitial liquid level equilibration.

11. Period ILL 98-03: interstitial liquid level May 14, 1998 to January 30, 2003, used linear change rate.

12. Period ILL 03-13: interstitial liquid level February 5, 2003 to June 13, 2013, used polynomial change rate.

Excel was used to calculate the regression equation for the trendline in each period. The first derivative was then calculated for each period formula to give the SL or ILL change rate at any point on the trendline.

The resulting change rates calculated for each of the time periods are plotted in Figure 22 . Figure 22 also includes the 1973 - 1974 level change rate (designated SL 73-74).

Figure 22 shows the level change rates in inches per year. Due to the varying amount of liquid on the surface the change rates are not directly comparable for the periods 1973-1974, 1979-1994, and 1995-2014. The 1973-1974 period had a 100\% liquid surface which correlates to $2,750 \mathrm{gal} / \mathrm{in}$. Per Section 4.2 the $1979-1994$ period is roughly estimated to average about $535 \mathrm{gal} / \mathrm{in}$. and the $1995-2013$ period about $485 \mathrm{gal} / \mathrm{in}$. 
RPP-RPT-54964, Revision 2

Figure 21 Expanded X-Axis and Y-Axis Plot of Tank T-111 Level Data

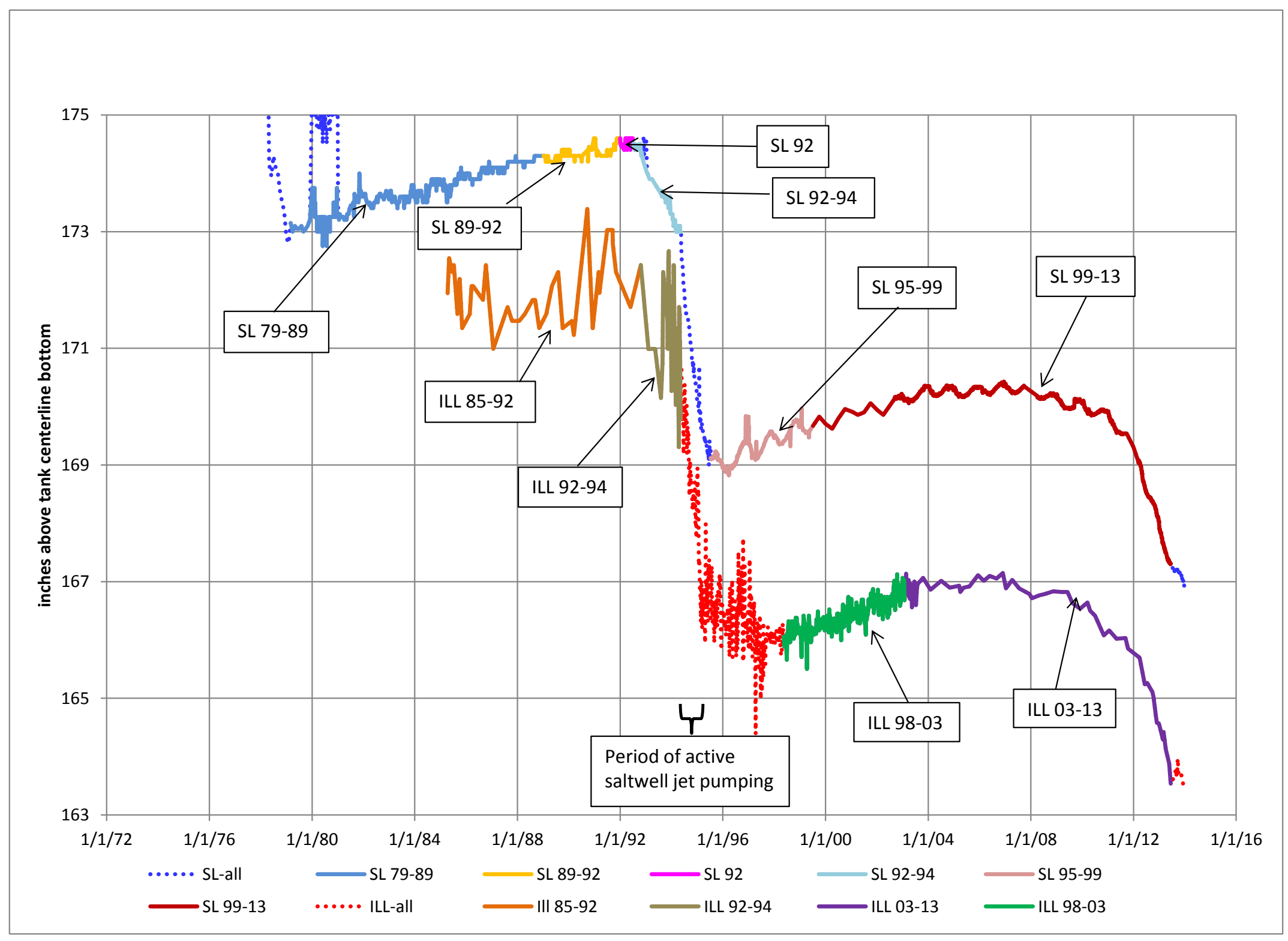


RPP-RPT-54964, Revision 2

Figure 22 Tank T-111 Surface and Interstitial Liquid Level Change Rates to June 13, 2013

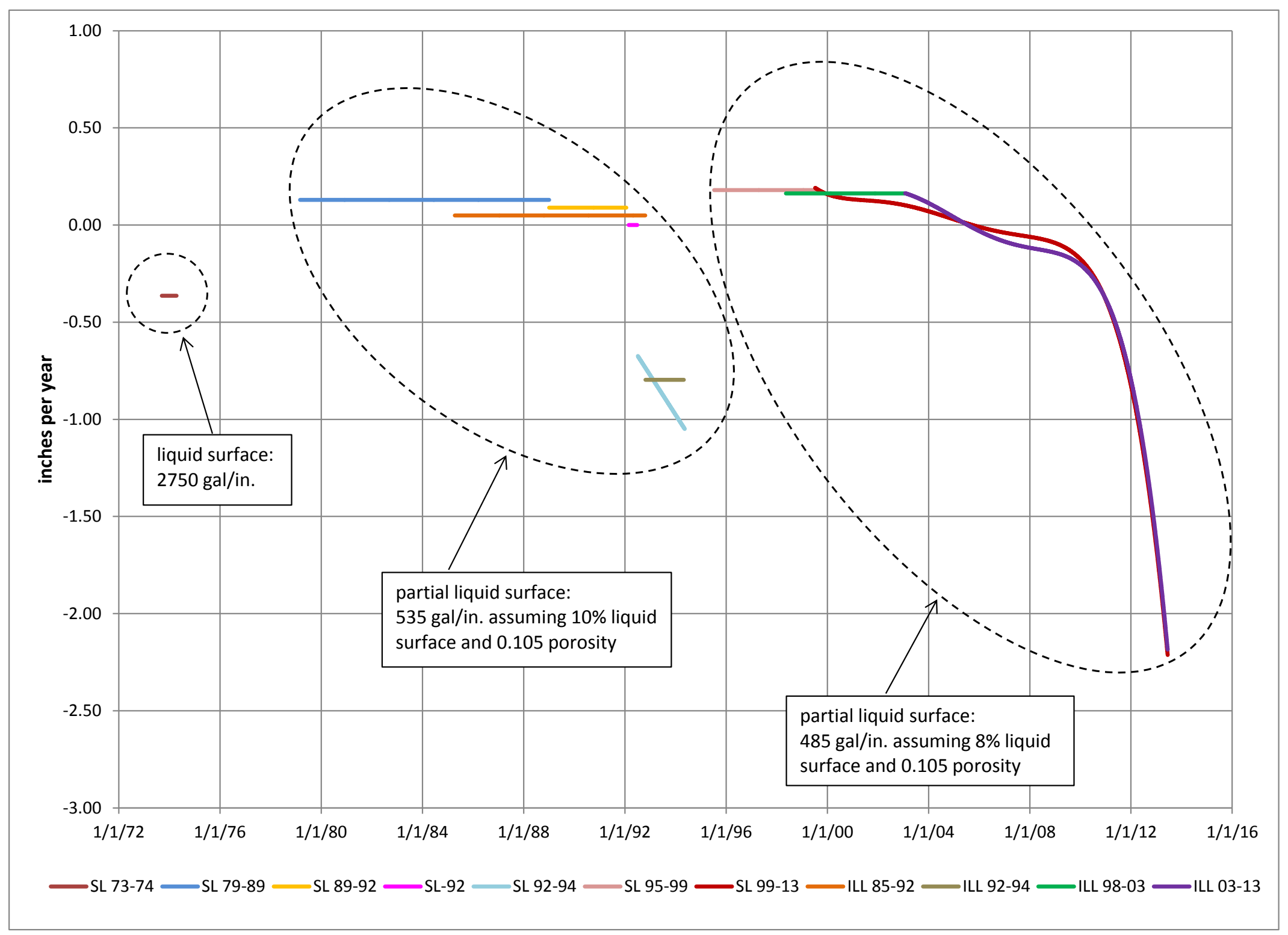


Tank T-111 is one of several tanks where the SL and ILL data track each other. This is due to the ILL being at or near the surface and the Enraf plummet is resting in liquid. The LOW and Enraf are on opposite sides of the tank for tank T-111 but the ILL and SL data track each other, as do the calculated ILL and SL change rates in Figure 22.

The calculated SL and ILL change rates for tank T-111 were averaged for each day from March 1, 1979 to June 13, 2013 and the resulting values plotted in Figure 23. A regression line through the post-1994 values was calculated in Excel to provide a formula for the tank T-111 level change rate between July 13, 1995 and June 13, 2013.

The change rate data from 1973 to 1974 and 1979 through 1994 are not used further in this document except to calculate volume per inch conversions in Section 4.2.

Based upon Figure 23, the tank T-111 liquid level change rate became negative around the beginning of 2006.

Surface Level and Interstitial Liquid Level Change Rates after June 13, 2013 - Figure 24 plots the SL and ILL change from January 1, 2013 to January 1, 2014. Both the SL and ILL data continued to decrease at about the same rate from the April 1, 2013 cutoff date used for Revs 0 and 1 of this document until the June-July time frame. The SL evened off in July and showed negligible change until late September when it began to decrease again. The ILL continued to decrease at about the same rate as before April until the June 13 data point. After that it rose slightly until it began to show a decrease again in September. Table 1 provides the Figure 24 linear change rate data from September 25, 2013 to January 1, 2014.

Table 1 Tank T-111 Level Change Rates After September 25, 2013

\begin{tabular}{|c|c|c|c|c|}
\hline Level Data & $\begin{array}{c}\text { Start } \\
\text { Date }\end{array}$ & End Date & $\begin{array}{c}\text { Decrease Rate } \\
\text { (in./day) }\end{array}$ & \multirow{2}{*}{ Average (in./day) } \\
\hline Surface Level & $9 / 25 / 2013$ & $1 / 1 / 2014$ & $-3.36 \mathrm{E}-03$ & \multirow{2}{*}{$3.34 \mathrm{E}-03$} \\
\hline Interstitial Liquid & $9 / 25 / 2013$ & $1 / 1 / 2014$ & $-3.31 \mathrm{E}-03$ & \\
\hline
\end{tabular}


RPP-RPT-54964, Revision 2

Figure 23 Tank T-111 Average Liquid Level Change Rates 1973 to June 13, 2013

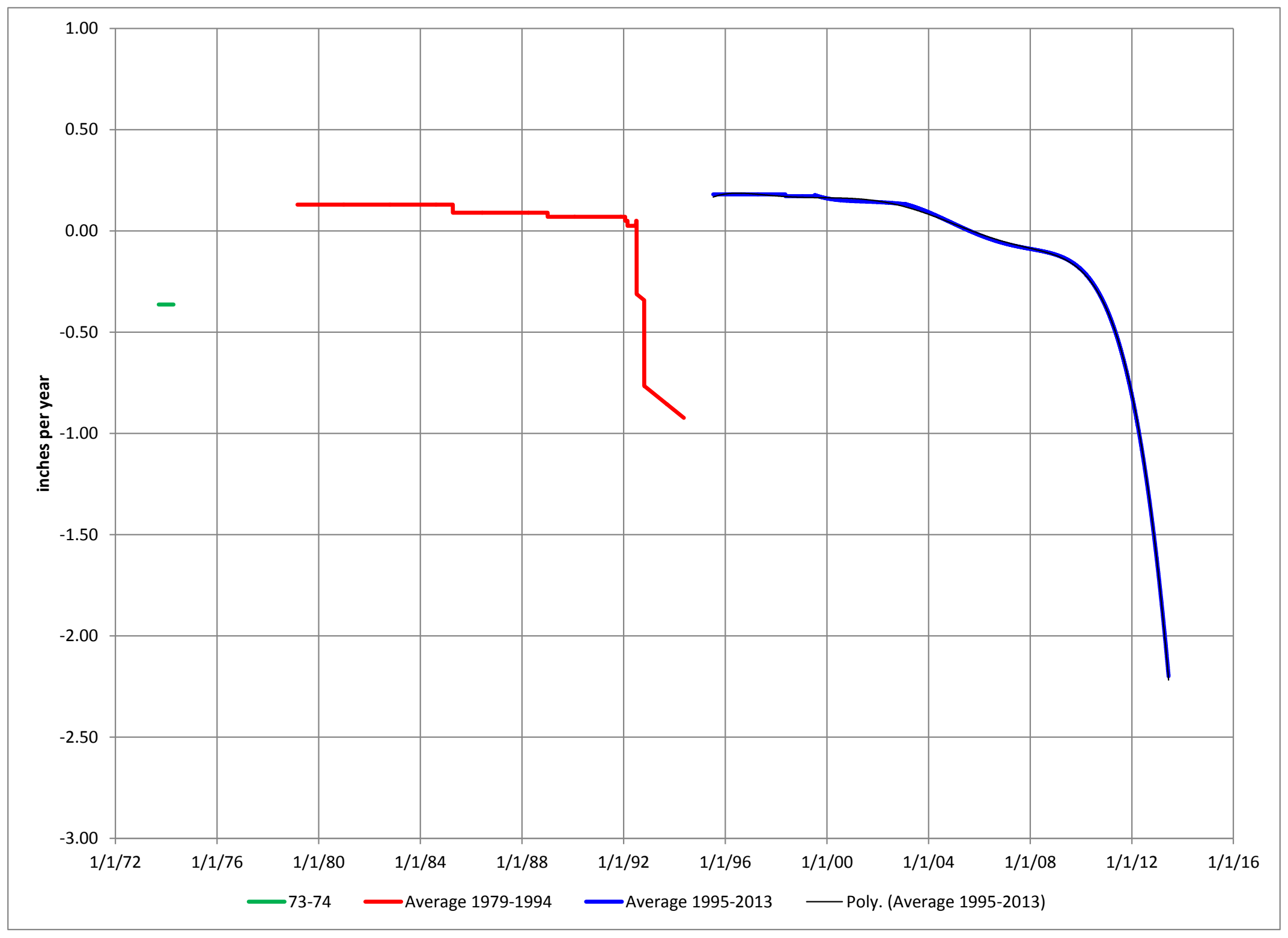


RPP-RPT-54964, Revision 2

Figure 24 Tank T-111 Surface and Interstitial Liquid Levels January 1, 2013 to January 1, 2014

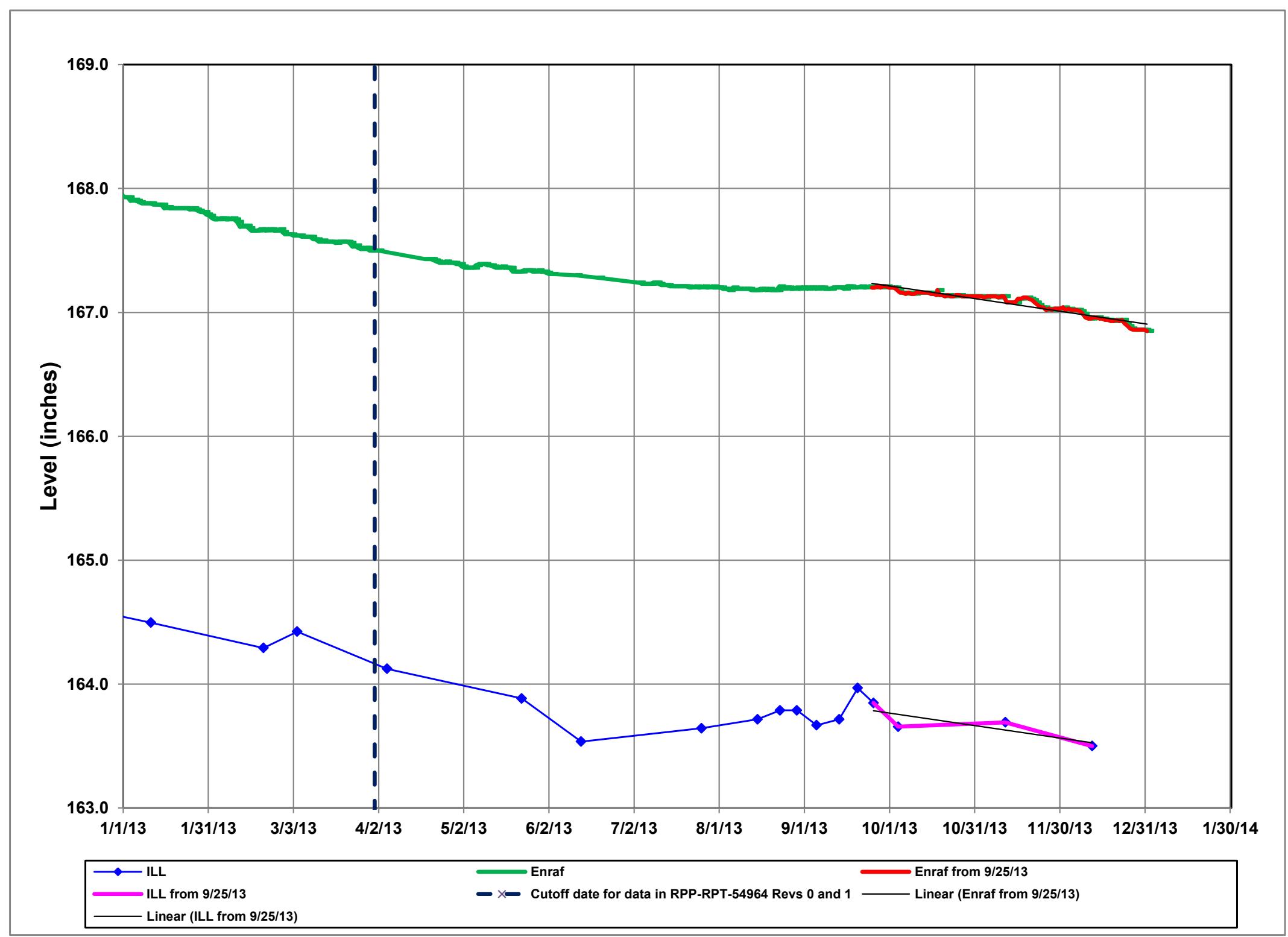




\subsection{Tank T-111 Volume Change Rate}

The estimated volume change rate for a $75 \mathrm{ft}$. diameter tank is:

where:

$$
\text { volumetric change rate }=L C R \text { in. } / y r \times 2,750 \frac{\text { gal }}{\text { in. }} \times(F S L+(1-F S L) \times \sigma)
$$

$\mathrm{LCR}=\Delta L=$ level change rate

$\mathrm{FSL}=$ fraction of waste surface that is liquid

$\sigma=$ waste porosity

Volume Change Rate September 13, 1973 to April 13, 1974 - Tank T-111 had a 100\% liquid surface before April 13, 1974 so FSL $=1.0$ and porosity $=0$. The above reduces to:

$$
\text { Tank } T-111 \text { volumetric change rate for } 1973-1974=2,750 \Delta L \frac{\mathrm{gal}}{\mathrm{in} .}
$$

Volume Change Rate March 1, 1979 to May 15, 1994 - Photos from 1978 and 1984 show the central pool in tank T-111 to be about the same size or slightly bigger than in 1994 photos and the 2013 videos. In the 1979 photos the waste surface is much wetter with few cracks compared to later.

Values used for porosity based upon interim stabilization data and/or estimating drainable liquid content for sludge in SSTs have ranged from 0.05 to 0.17 . Most sludge porosity values used for general SST estimates have been around 0.12. The saltwell pumping information for tank T-111 in HNF-SD-RE-TI-178, Rev 9a, indicates a porosity of 0.105 based upon dip tube measurements. Based upon the difficulty of saltwell pumping in tank T-111 in both the 1970s and 1990s it is apparent that the tank T-111 waste has a low porosity, or at least a low drainability. For the purposes of this document it is assumed that tank T-111 waste has a porosity of 0.105 , the same as estimated at the end of interim stabilization in 1995 and given in HNF-SD-RE-TI-178, Rev 9A. This value is also used to estimate the tank T-111 drainable interstitial liquid volume for HNF-EP-0182, Rev. 307.

Using an engineering estimate of 10\% surface liquid for 1979-1994 (compared to the 8\% estimated below for 1995 to 2013) results in:

volumetric change ratefor 1979 to 1994

$$
=(\Delta L) \times\left(2750 \frac{\text { gal }}{\text { in. }}\right) \times(0.10+((1-0.10) \times 0.105))=535 \Delta L
$$

Volume Change Rate July 13, 1995 to June 13, 2013 - The February 2013 video image was estimated to have a nominal $20 \mathrm{ft}$. diameter pool based upon engineering judgment and comparison to the $10 \mathrm{in}$. diameter saltwell screen. The fraction of the tank T-111 waste surface that is liquid, for a $20 \mathrm{ft}$. diameter pool, is $20^{2} \div 75^{2}=0.071$. This was rounded up to 0.08 .

The volumetric change rate for tank T-111 for 1995 to 2013 is assumed to be:

volumetric change rate for 1995 to 2013

$$
=(\Delta L) \times\left(2750 \frac{\text { gal }}{\text { in. }}\right) \times(0.08+((1-0.08) \times 0.105))=485 \Delta L
$$

Values for $\Delta \mathrm{L}$ obtained from the regression line formula for the plot in Figure 23 are used in the above equation to estimate a daily volume change rate from 1995 to June 13, 2013. Figure 25 gives the results. 
RPP-RPT-54964, Revision 2

Figure 25 Calculated Tank T-111 Volume Change Rate July 13, 1995 to June 13, 2013

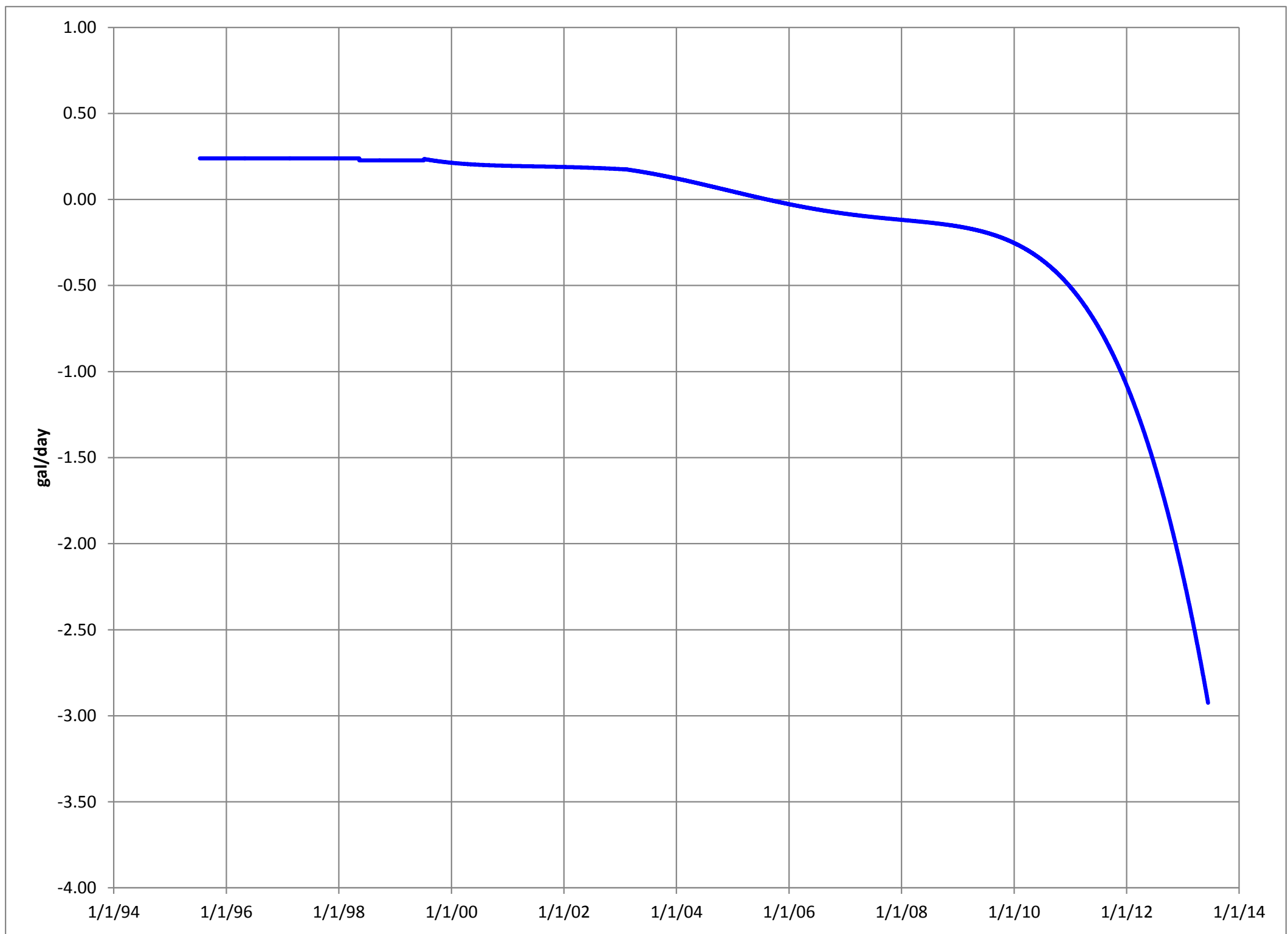




\section{RPP-RPT-54964, Revision 2}

Volume Change Rate after June 13,2013 - A volume change rate is not calculated for the period June 13 to September 25, 2013 as it would be meaningless with the ILL data showing a small increase and the SL data showing no change or a slight decrease.

The rate from September 25, 2013 to January 1, 2014 calculates to -1.6 gal/day using the Table 1 value of 3.34E-03 in./day and $485 \mathrm{gal} / \mathrm{in}$.

\subsection{Data Analysis}

Changes in the SL or ILL data do not necessarily mean the SL or ILL is changing. Analysis of the data is necessary to interpret what is occurring. Factors that could cause a change in the SL or ILL data are listed in Table 2.

Table 2 Factors Impacting Surface Level or Interstitial Liquid Level Data

\begin{tabular}{|c|l|}
\hline & \multicolumn{1}{|c|}{ Factor } \\
\hline 1 & ILL increase and/or SL decrease due to consolidation/slumping of waste into pores. \\
\hline 2 & Gas generation and entrapment within the waste causing level increase. \\
\hline 3 & Release of retained gas entrapped within the waste causing a level decrease. \\
4 & $\begin{array}{l}\text { Conscious liquid additions to the tanks such as core sampling drill string flushes, core } \\
\text { sampling head fluid additions, level gauges flushes, water lancing of equipment during } \\
\text { installation, grab sample flushes. }\end{array}$ \\
\hline 5 & Chemical changes within the waste. \\
\hline 6 & ILL not at equilibrium following LOW installation or saltwell pumping (ILL only). \\
\hline 7 & $\begin{array}{l}\text { Level gauge plummet resting on uneven solid surface, (plummet rests on different spot } \\
\text { when raised and lowered, or surface resistance changes), gauge maintenance or } \\
\text { calibration problems, changing of tank reference location for zero level (SL only). }\end{array}$ \\
\hline 8 & Water intrusion for level data increase. \\
\hline 9 & Evaporation for level data decrease. \\
\hline 10 & Tank leak for level data decrease. \\
\hline
\end{tabular}

The intrusion rate, Factor 8 in Table 2, is positive or zero, the evaporation rate and leak rate, Factors 9 and 10, are negative or zero, and the net impact of Factors 1 through 5 in Table 2 may be either positive or negative.

Factor 6 is a subjective assessment based upon review of the ILL data plot trend and, if necessary, the raw neutron count data. There is no numerical value associated with Factor 6. Rather, it is a judgment as to whether the net level change rate estimate shows a change to the liquid level in the tank or a redistribution of the liquid as it slowly seeks an equilibrium level.

Factor 7 is an assessment based upon review of the SL data plot trend and any data available. If the plummet is resting on liquid or a reasonably flat solid surface, data changes can be assumed to represent changes in the waste surface. Some tanks have had problems with the level gauge operation that resulted in misleading data trends, this became evident when the level gauge maintenance history was reviewed. 


\section{RPP-RPT-54964, Revision 2}

The volumetric change rate is the sum of:

- Liquid addition to and/or removal from the tank

- Retained gas growth in and/or release from the tank

- Loss of gas due to porosity decrease

- Waste density change due to chemical changes

The tank volumetric change rate is equal to the net effect of intrusion, evaporation, leaks, and all other factors:

volumetric change rate $=$ intrusion rate + evaporation rate + leak rate $+\Sigma$ other where $[\Sigma$ other] equals the net impact of:

- ILL increase and/or SL decrease due to consolidation/slumping of porous waste

- Gas generation, entrapment, and release within the waste causing level increase or decrease

- Conscious liquid additions to the tanks such as core sampling drill string or grab sample bottle flushes, core sampling head fluid additions, level gauges flushes, water lancing of equipment during installation

- Chemical changes within the waste

The following subsections provide an estimate for the $[\Sigma$ other $]$ factor.

Physical Waste Changes - The first part of [ $\Sigma$ other] concerns waste subsidence, or compression of the waste above the ILL onto the open pores. Physical changes are more likely to occur with saltcake rather than sludge due to the greater potential for chemical changes with time and the potential for the waste to compress due to the higher saltcake porosity. Tank T-111 is all sludge filled with interstitial liquid almost to the waste surface so there is little room for the waste to subside on itself. There is no reason to suspect significant physical changes continuing to occur within the waste. There are no known physical changes that could be causing the change in SL and ILL data. The last waste was received in the tank in 1956; interim stabilization liquid removal was not significant after 1974; and waste temperature changes are minimal. After this much time it is unlikely that the waste is going to begin changing much physically. It is assumed there is no impact of waste changes on the tank T-111 level change rate.

The physical waste change portion of [ $\Sigma$ other] is assigned a value of zero.

Gas Generation and Release - The second part of [ $\Sigma$ other] is the effect of retained gas on the level change. This Section 4.3 looks at all potential impacts on the tank level data for completeness, but barring an overlooked issue the cyclical level change pattern for tank T-111 seen in Figure 21 has three possible explanations. They are:

1. The tank retains gas for a decade or more and then releases it slowly over a nominal five to seven years, there is no tank leak.

2. The level changes are due to a combination of intrusion and leaking. When the intrusion rate exceeds the leak plus evaporation rate the level rises. When the intrusion rate is less than the leak plus evaporation rate the level falls.

3. A combination of these two explanations. 


\section{RPP-RPT-54964, Revision 2}

This subsection looks at the potential for the level increases and decreases to result from gas retention and release.

The volume of retained gas in a tank is unknown, but the relative volume can be sometimes be inferred from combined plots of the ILL and the inverse of atmospheric pressure vs. time. If sufficient retained gas is present in a tank an increase in the atmospheric pressure will result in a small decrease in the ILL level as the gas bubbles are compressed, and a decrease in the pressure will result in a small increase in the ILL level. Predominantly saltcake tanks have a more rigid waste matrix and thus the ILL may move up and down a small amount depending upon the volume of retained gas. Predominantly sludge tanks do not have a rigid waste matrix and show far less or no response to atmospheric pressure.

Figure 26 is a retained gas plot for tank T-111 prepared using Excel file BP Correlation with DB Connect, SVF-1002, June 27, 2005. This file was developed to enable surveillance personnel to assess retained gas content of tanks. It downloads the hourly atmospheric data from the Hanford Site Weather Station (HWS) and the tank SL or ILL data from the Personal Computer Surveillance Analysis Computer System (PC-SACS) database, scales the data, adds a slope where helpful for display, and calculates an $\mathrm{R}^{2}$ value for the two data files to show the degree of correlation. The higher the $\mathrm{R}^{2}$ value (closer to 1.0 ) the better correlation between the ILL reading and barometric pressure and thus the more gas there is in the tank, the lower the $\mathrm{R}^{2}$ value (closer to 0.0 ) the less correlation and thus less gas is present and being retained. The $\mathrm{R}^{2}$ value for Figure 26 is 0.126 , indicating a low correlation. Figure 26 is based upon ILL data prior to August 2003. ILL measurements were changed from weekly to monthly/quarterly after August 2003 and there is insufficient annual data since to provide a useful plot. If there is retained gas in a tank in 2013, it would have been present in 2003.

Tank T-111 exhibited several very long periods of level increase, but no sudden decreases. The current decrease has been going on since at least 2008 except for the three month pause in the summer of 2013. A long level increase could be due to an intrusion or gas buildup. Experience with DSTs has shown that tanks with liquid and saltcake tend to buildup gas and then release a portion of it in a short period of time. Tanks with sludge are believed to build up gas until the matrix is not strong enough to retain any more gas, at which point the gas is released more or less as generated or the barometric pressure changes (RPP-RPT-26836, 2010, Gas Retention and Release from Hanford Site High Shear Strength Waste, Rev 0).

Figure 8 shows numerous small depressions on the tank T-111 waste surface. Most views of the tank T-111 waste surface show these small depressions. These may be gas release points from the sludge, as described in RPP-RPT-26836. If they are gas release points this means there is a gas reserve of unknown volume in the tank and the gas is released via numerous paths to the waste surface with changes in atmospheric pressure.

The potential for gas buildup and release in tank T-111 was evaluated in RPP-RPT-54305, Initial Assessment for Potential Gas Release Events in Hanford Site Deep Sludge Double-Shell Tank Waste, 2013, and concluded to not be of concern for tank T-111. 
RPP-RPT-54964, Revision 2

Figure 26 Tank T-111 ILL vs. Inverse Barometric Pressure, August 2001 to August 2003

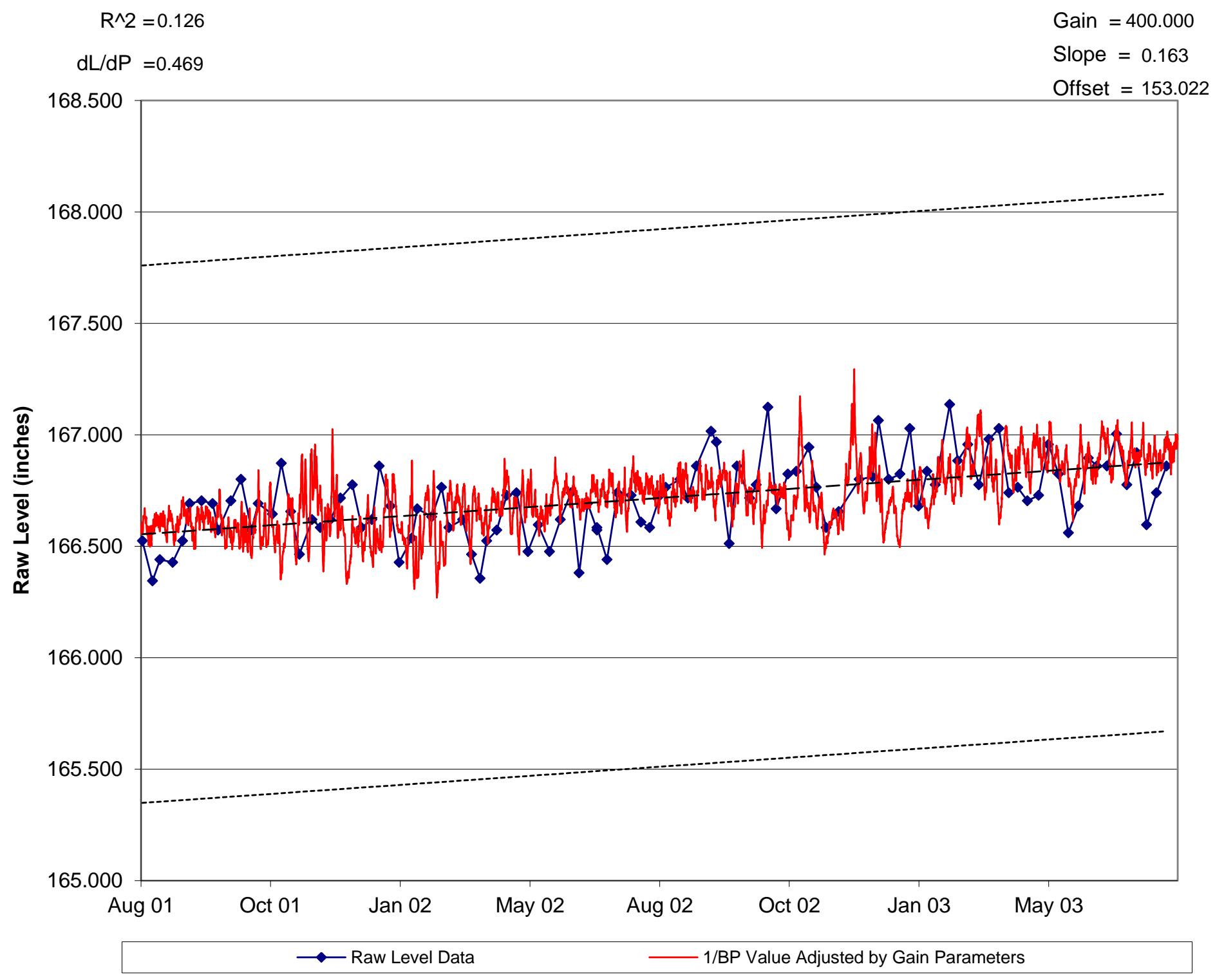




\section{RPP-RPT-54964, Revision 2}

If the level changes in tank T-111 are due to gas buildup and release then the increase and decrease should roughly match. The 1.8 inch waste level increase based upon SL data in the 13.8 years between early February 1979 and late November 1992 was roughly the same as the 1.6 inch SL decrease in the 1.5 years between late November 1992 and mid-May 1994, but the initiation of saltwell pumping in May 1994 cut short the comparison time for this cycle.

For the next cycle the 1.4 inch SL increase in the 11.4 years between mid-June of 1995 and mid-November 2006 is only $40 \%$ of the 3.6 inch SL decrease in the 7.1 years between mid-November 2006 and January 1, 2014. This second SL cycle change is mirrored in the 1.3 inch ILL increase in the 9.6 years between mid-April 1997 and late November 2006 followed by the 3.6 inch ILL decrease in the 7.0 years between late November 2006 and mid-December 2012.

What this means is that in the second T-111 cycle there was 2.5 times the decrease as increase. In the first cycle the increase and decrease were roughly the same but the decrease cycle was truncated by saltwell pumping. These numbers are rough, but if the level change was due to gas it is not easy to explain how 2.5 times the volume of gas was released as generated.

The SL and ILL decrease rates from 2006 to 2014 are equivalent to releasing a volume of gas in the range of 0.15 to $0.4 \mathrm{ft}^{3} / \mathrm{d}$ depending upon what pressure is assumed near the bottom of the waste in tank T-111 and using the 485 gal/in. factor from Section 4.2 for the 1995 to 2013 time period.

Table 3 summarizes the gas monitoring data taken prior to tank entry during the tank T-111 videos. Other than the 217 parts per billion for Volatile Organic Carbon (VOC) observed on the first entry, there has been no hydrogen or ammonia detected. Based upon an assumed $2.22 \mathrm{cfm}$ breathing rate for the tank (see Section 4.5), and an approximate 53,800 $\mathrm{ft}^{3}$ tank T-111 headspace, if the tank were releasing $0.4 \mathrm{ft}^{3}$ of mixed waste gas per day from the waste the tank should have an equilibrium mixed waste gas concentration of a little over $125 \mathrm{ppm}$ in the tank headspace. It would take about a week and a half from the time gas release began to reach $50 \%$ of this value.

Mixed waste gases usually contain hydrogen, ammonia, nitrous oxide, nitrogen, and occasionally other gases. If the waste gas were 10 volume percent hydrogen the equilibrium hydrogen concentration would be about $12.5 \mathrm{ppm}$. Since hydrogen wasn't sampled for except once, and ammonia isn't always present in the waste gas, the data in Table 3 are not conclusive that the tank isn't releasing waste gas, but it does indicate it isn't likely.

The TWINS database was queried on January 8, 2014 for additional hydrogen and ammonia vapor data from tank T-111. The results are provided in Table 4. The January 20, 1995 data were obtained near the end of saltwell jet pumping. Experience showed retained gases were frequently released during saltwell jet pumping as the liquid head pressure in a tank was reduced. Although ammonia was present in the sample, it is frequently present in low concentrations in many tanks as it is a soluble gas. The fact that hydrogen was below detectible limits indicates that retained gas release from the tank was not significant at this time.

Gas generation in an SST is a function of a number of factors including, but not limited to, temperature, the disintegration energy level of the radionuclides in the tank, the concentration of the radionuclides, and the concentration of surrounding constituents which absorb the radiation and generate gases when the absorbed radiation breaks chemical bonds. RPP-5926, 2013, Steady-State Flammable Gas Release Rate Calculation and Lower Flammability Level 
Evaluation for Hanford Tank Waste, Rev 13, discusses all the factors and provides a conservative estimated hydrogen generation rate $0.60 \mathrm{ft}^{3} / \mathrm{d}$ for tank $\mathrm{T}-111$ in Table $7-6$ of that document.

A conservative hydrogen generation rate of $0.60 \mathrm{ft}^{3} / \mathrm{d}$ is in the same range as the average 0.15 to $0.4 \mathrm{ft}^{3} / \mathrm{d}$ range of total waste gas that would have been released from 2006 to 2014 if the level drop in this period were due solely to gas release. The $0.60 \mathrm{ft}^{3}$ of hydrogen/d is based upon a steady state generation rate. The 0.15 to $0.4 \mathrm{ft}^{3} / \mathrm{d}$ range of total waste gas is the rate at which gas would need to be released to approximate the average tank level decrease from 2008 to 2014 .

Table 3 Gas Monitoring Data Taken Prior to Tank Entry for Tank T-111 Videos

\begin{tabular}{|c|c|c|c|c|}
\hline $\begin{array}{l}\text { Date of } \\
\text { Reading }\end{array}$ & $\begin{array}{c}\text { Flammable } \\
\text { Gas }\end{array}$ & Ammonia & $\begin{array}{l}\text { Volatile } \\
\text { Organic } \\
\text { Carbon }\end{array}$ & $\begin{array}{c}\text { Direct Reading } \\
\text { Instrument (DRI) Survey } \\
\text { Number }\end{array}$ \\
\hline $1 / 31 / 131415$ & $\mathrm{NA}^{1}$ & $0.000 \mathrm{ppm}^{2}$ & $217 \mathrm{ppb}^{2}$ & $13-00452$ \\
\hline 2/11/13 1000 & NA & 0.000 ppm & $0.000 \mathrm{ppb}$ & $13-00574$ \\
\hline $2 / 11 / 131025$ & $\mathrm{NA}$ & $0.000 \mathrm{ppm}$ & $0.000 \mathrm{ppb}$ & $13-00574$ \\
\hline 2/11/13 1310 & NA & $0.000 \mathrm{ppm}$ & $0.000 \mathrm{ppb}$ & $13-00574$ \\
\hline $3 / 20 / 131045$ & NA & 0.000 ppm & $0.000 \mathrm{ppb}$ & $13-01135$ \\
\hline $3 / 20 / 131055$ & NA & $0.000 \mathrm{ppm}$ & $0.000 \mathrm{ppb}$ & 13-01135 \\
\hline $12 / 30 / 131050$ & NA & $0.000 \mathrm{ppm}$ & $0.000 \mathrm{ppb}$ & $13-04883$ \\
\hline $12 / 30 / 131308$ & NA & $0.000 \mathrm{ppm}$ & $0.000 \mathrm{ppb}$ & $13-04883$ \\
\hline 12/30/13 1309 & $\begin{array}{c}0.000 \% \mathrm{LEL}^{3} \\
20.9 \% \mathrm{O}_{2}\end{array}$ & NA & NA & $13-04883$ \\
\hline \multicolumn{5}{|c|}{$\begin{array}{l}{ }^{1} \text { RPP-RPT- } 54964, \text { Rev } 1 \text {, states work package TFC-WO-12-5616 gives the flammable gas } \\
\text { reading for this date as } 0 \% \text { of the LFL. This reading could subsequently not be found in the } \\
\text { work package and is not listed on the DRI form. } \\
2 \text { VOC was erroneously reported as } 216 \text { ppm ammonia in RPP-RPT-54964, Rev } 1 . \\
{ }^{3} 1.0 \% \text { LEL equals } 10,000 \text { ppm } \mathrm{H}_{2} \\
4 \text { DRI surveys obtained from industrial hygiene database, see References - DRI Forms }\end{array}$} \\
\hline
\end{tabular}

Table 4 Additional Tank T-111 Headspace Sample Data from TWINS

\begin{tabular}{|c|c|c|}
\hline $\begin{array}{c}\text { Date of } \\
\text { Reading }\end{array}$ & Hydrogen & Ammonia \\
\hline $1 / 20 / 95$ & $<94 \mathrm{ppm}$ & $227 \mathrm{ppm}$ \\
\hline $8 / 7 / 08$ & $\mathrm{NA}$ & $1.14 \mathrm{ppm}$ \\
\hline $8 / 11 / 08$ & $\mathrm{NA}$ & $0.76 \mathrm{ppm}$ \\
\hline
\end{tabular}


Document RPP-RPT-55084, Hanford 241-T Farm Leak Inventory Assessment Report, Rev 0, states: "...tank T-111 has 10 times the total organic carbon in the waste compared to other T Farm tanks. High organic carbon has been linked to the formation of gas." Per the same document the higher organic carbon levels were noted in the top layers of the tank waste. It would not be expected that the waste near the top of a tank would retain a significant volume of gas.

The following summarize the preceding gas buildup and release discussion:

- Sludge containing SSTs have not shown a buildup and release cycle like in tank T-111 in any other tank.

- RPP-RPT-54305 evaluates the potential for gas release from tank T-111 to be low.

- A plot of level vs. the inverse of the barometric pressure plot for tank T-111 shows little correlation between the two, although sludge tanks normally do not show much correlation.

- RPP-RPT-26836 evaluates sludge strength properties for tank wastes and concludes the properties of sludge wastes will permit retaining a limited volume of gas; above that volume the gas is released with variation in the head pressure. Tank T-111 is used as an example in RPP-RPT-26836 of the limited ability of sludge tanks to retain significant volumes of gas.

- There are numerous indentations on the tank T-111 waste surface which could be gas release points similar to those predicted in RPP-RPT-26836.

- The loss of waste volume between 2006 and 2014 was 2.5 times the volume gain between 1995 and 2006. If the level changes were due to gas buildup and release, the release of significantly more gas than generated is not readily explainable.

- No hydrogen or ammonia gases, both retained gas markers, were noted in the tank headspace during monitoring performed prior to intrusive activities for the tank videos.

- No hydrogen was noted in other tank T-111 headspace monitoring in 1995 and 2008. Ammonia was noted in the tank headspace in 1995 near the end of saltwell pumping and low ammonia levels noted in 2008.

- The level decrease rate for 2006 to 2014 is in the same general range as the conservatively estimated hydrogen generation rate for tank T-111 in RPP-5926, Rev 13.

Most of these indicate that the cyclical level changes in tank T-111 were not due to gas buildup and release. Some information does indicate that gas generation in the tank is possible, but it doesn't explain the long release cycle.

It is concluded for this document that gas generation and release is not a significant factor in the observed cyclical waste level in tank T-111.

The gas generation and release portion of [ $\Sigma$ other $]$ is assigned a value of zero. 
Water Additions to The Tank - Known liquid additions make up the third part of [ $\Sigma$ other]. No large items of equipment are known to have been lanced into the tank in the past 10 years and the TWINS database indicates no samples have been taken from the tank in that time. Water usage data sheets were not reviewed, but making the assumption that a level gauge is flushed with a nominal 10 gal of water every two years results in a nominal 5 gal/yr conscious liquid addition.

The water addition portion of [ $\Sigma$ other] is assigned a value of $5 \mathrm{gal} / \mathrm{yr}$.

Chemical Waste Changes The last waste was put into the tank in 1956. The assumption is made that any significant chemical changes that may occur within the waste have already occurred, the potential for chemical reactions to cause changes and affect the level data is small.

The chemical change portion of [ $\Sigma$ other] is assigned a value of zero.

Data Analysis Summary - Based upon the preceding subsections the value [ $\Sigma$ other] for tank $\mathrm{T}-111$ is assumed to be $=0+0+5+0=5 \mathrm{gal} / \mathrm{yr}$.

\subsubsection{Evaluation of ILL and SL Validity}

ILL Not at Equilibrium following LOW Installation or Saltwell Pumping - The LOW in tank T-111 was installed in 1985 and the ILL has roughly tracked the surface level monitoring device since shortly after LOW installation. The ILL has gone up and down with the saltwell pumping in 1994 to 1995 and the apparent intrusions before and after the 1994 to 1995 saltwell pumping. The LOW and Enraf gauge are on opposite sides of the tank (65 to $70 \mathrm{ft}$ apart) and track each other closely. The ILL is just below the waste surface and is definitely reading a similar level as the Enraf plummet.

In some SSTs the ILL has shown to take many years to reach equilibrium following saltwell pumping. Both of the long term level increase periods in tank T-111 took place following saltwell pumping. If the LOW and the surface level gauge were located next to the saltwell screen, the pattern seen in Figure 21 might be expected because the liquid level in the waste around the saltwell screen would have been drawn down by the pumping and would be expected to rise as the liquid seeked equilibrium. The LOW and surface level gauge are on the outer edge of the tank however and the saltwell screen is in the center. For this arrangement the liquid level should have continued to drop following cessation of pumping, not risen.

Enraf Plummet Not Resting Correctly - The in-tank videos taken on February 11, 2013 and December 31, 2013 show the plummet is resting in a small depression and is not hung up on any waste surface that would skew the level data trend. The plummet normally registers the waste surface in a tank or the surface at the bottom of a depression, in tank T-111 it is measuring the interstitial liquid level that is only a few inches below waste surface. For tank T-111 the plummet is giving consistent trend data that reflect the ILL in the tank. From the video image in Figure 12 the plummet may no longer track the ILL within a few years, or less as the liquid continues to disappear beneath it.

Recalibration of Level Gauge - Most if not all of the T-111 surface level data up to July 13, 1995 were obtained with an FIC gauge. It is possible that some of the data in the early to mid-1970s was obtained with a manual tape. When the switch from an FIC gauge to an Enraf was made on July 13, 1995 the first Enraf reading was only 0.13 inches different than the FIC reading. This change is far less than the step change usually seen with a gauge type change, and is inconsequential to the surface level data trend information used in this document. 
RPP-RPT-54964, Revision 2

Enraf calibration records were reviewed for the 2007 to 2013 period and are summarized in Table 5.

Table 5 Tank T-111 ENRAF Gauge Work Packages Since January 1, 2007

\begin{tabular}{|c|c|c|c|c|}
\hline Work Package No. & Title & Date & $\begin{array}{c}\text { As Found } \\
\text { (in.) }\end{array}$ & $\begin{array}{c}\text { As Left } \\
\text { (in.) }\end{array}$ \\
\hline CLO-WO-1250 & 241-T, 111 ENRAF INSPECTION & September 4, 2007 & 170.33 & 170.36 \\
\hline TFC-WO-09-1853 & 241-T, 111 ENRAF INSPECTION & September 10, 2009 & 169.99 & 170.1 \\
\hline TFC-WO-11-3306 & 241-T, 111 ENRAF INSPECTION & December 30, 2011 & 169.38 & 169.31 \\
\hline
\end{tabular}

The differences between the As Found and As Left values have negligible impact on the level data regression line slopes.

Change of Tank Level Reference - The change from using the bottom of the tank knuckle to using the tank centerline bottom as the reference point for tank T-111 level gauge data was made on September 18, 1995. This change is reflected in the tank T-111 data plots by the addition of 12 inches (the elevation difference between the bottom of the tank knuckle and the tank centerline bottom) to all waste surface level data before September 18, 1995 used in this document, unless otherwise specified. No change is necessary for the ILL data since these values were already referenced to the bottom centerline of the tank.

Summary - The surface level and interstitial liquid level values are valid and reflect actual conditions in the tank.

\subsection{Intrusion Rate Estimate}

From Figure 21 it can be seen that the intrusion rate, the leak rate, or both, vary over time. In Section 4.6 the leak rate is presented as a function of various assumed intrusion rates. Section 4.4 provides an estimated range for intrusion rates to use in Section 4.6.

The only direct estimate of the intrusion rate that is independent of the leak rate is that obtained from the videos on December 30 and December 31, 2013. Per Section 3.3 the intrusion rate at that time is estimated to be 8.5 drips per minute. This corresponds to an intrusion rate of 0.16 to $0.81 \mathrm{gal} / \mathrm{d}$, or 60 to $300 \mathrm{gal} / \mathrm{yr}$ assuming the intrusion is present for 365 days per year. The range is dependent upon whether it is assumed there are 20 drops per $\mathrm{mL}$ or 4 drops per $\mathrm{mL}$. The size of a drop can vary depending on the liquid physical properties as well as the size and shape of the opening from which it comes. A value of 20 drops per $\mathrm{mL}$ is the 'rule of thumb' value assumed for most laboratory use, but a value of four drops per $\mathrm{mL}$ is given by the U. S. Geological Survey at: http://ga.water.usgs.gov/edu/sc4.html based upon testing of pressurized water lines.

No drops were noted in the February 11, 2013 video, but this was due to oversight from not observing the liquid pool from a close enough viewpoint. Reflections were later seen on the tank dome from ripples on the pool surface, indicating there was an intrusion occurring. Comparing the droplets on the dome in Figure 11 and Figure 17, engineering judgment is used to estimate the intrusion rate in February 2013 was possibly about 75 percent of that in December 2013, a range of 0.12 to $0.61 \mathrm{gal} / \mathrm{d}$ ( 45 to $225 \mathrm{gal} / \mathrm{yr}$ ). 


\section{RPP-RPT-54964, Revision 2}

These are the only intrusion estimates practical which are not impacted by evaporation and a potential leak rate. If it is assumed the tank was not leaking in the mid-1995 to mid-1998 period, the $0.24 \mathrm{gal} / \mathrm{d}$ level increase rate at that time, from Figure 24, calculates to a $0.37 \mathrm{gal} / \mathrm{d}$ (135 gal/yr) intrusion rate after adjustment for the $0.13 \mathrm{gal} / \mathrm{d}$ (48 gal/yr) evaporation estimate provided in Section 4.5.

To summarize the intrusion rate estimates:

- 0.16 to $0.81 \mathrm{gal} / \mathrm{d}$ (60 to $300 \mathrm{gal} / \mathrm{yr}$ ) in December 2013

- 0.12 to $0.61 \mathrm{gal} / \mathrm{d}$ (45 to $225 \mathrm{gal} / \mathrm{yr}$ ) in February 2013

- $0.37 \mathrm{gal} / \mathrm{d}$ (135 gal/yr) average 1995 to 1998

An estimate of 100 to $150 \mathrm{gal} / \mathrm{yr}$ for a tank T-111 intrusion rate seems reasonable. Leak rate estimates are calculated for an intrusion rate range of zero to $300 \mathrm{gal} / \mathrm{yr}$ (zero to $0.81 \mathrm{gal} / \mathrm{d}$ ).

\subsection{Evaporation Rate Estimate}

RPP-RPT-54981, Rev 0, Appendix A, provides a methodology for estimating evaporation rates from SSTs, and provides an evaporation plot for tank T-111. Figure 27 shows the estimated evaporation rate from tank T-111 vs. relative humidity in the tank headspace. The estimated annual evaporation rate of $-48 \mathrm{gal} / \mathrm{yr}(-0.13 \mathrm{gal} / \mathrm{d})$ is where the estimated average headspace relative humidity crosses the evaporation rate line. The estimated average relative humidity for tank T-111 is derived in RPP-RPT-54981, Rev 0, Appendix A.

The tank headspace air temperature is largely dependent upon the waste heat generation rate. The Best Basis Inventory (BBI) lists 46 radionuclides in the tank T-111 waste. Of these, only nine contribute greater than $0.01 \%$ of the heat generation rate. Table 6 lists these radionuclides along with a calculated heat generation rate.

The 223 British Thermal Unit (BTU)/hr radiolytic heat generation rate for the tank is very low, and has negligible effect on the volume of water evaporated since most of this heat is lost to the surrounding soil. Although a $-48 \mathrm{gal} / \mathrm{yr}$ evaporation rate will only require $\sim 44 \mathrm{BTU} / \mathrm{hr}$ of heat input, the heat to evaporate the water in tank T-111 comes primarily from latent heat in the incoming air and the top few inches of the tank waste. 
RPP-RPT-54964, Revision 2

Figure 27 Tank T-111 Estimated Evaporation Rate

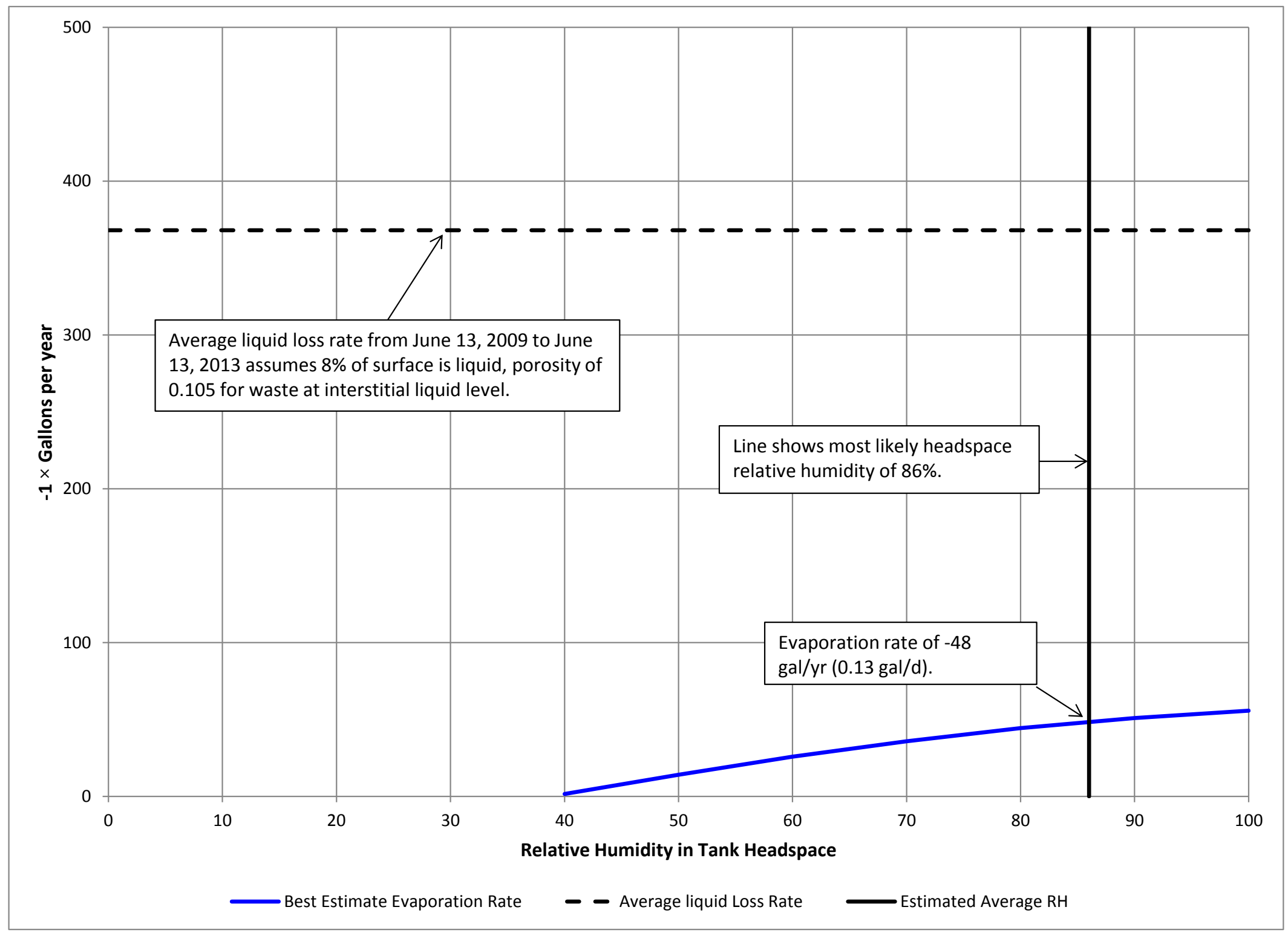


RPP-RPT-54964, Revision 2

Table 6 Radionuclides Contributing Greater Than 0.01\% to the Tank T-111 Waste Heat Generation Rate

\begin{tabular}{|c|c|c|c|}
\hline Radionuclide & $\mathbf{C i}^{1}$ & Heat Generation Rate (watts/Ci) ${ }^{2}$ & Heat Generation Rate (watts) \\
\hline $90 \mathrm{Sr}$ & $7.77 \mathrm{E}+03$ & $6.70 \mathrm{E}-03$ & $5.20 \mathrm{E}+01$ \\
\hline $90 \mathrm{Y}$ & $7.77 \mathrm{E}+03$ & $0.00 \mathrm{E}+00$ (with parent) & $0.00 \mathrm{E}+00$ \\
\hline 99Tc & $1.66 \mathrm{E}+01$ & 5.99E-04 & 9.94E-03 \\
\hline 137Cs & $1.95 \mathrm{E}+02$ & $4.82 \mathrm{E}-03$ & 9.39E-01 \\
\hline $137 \mathrm{mBa}$ & $1.84 \mathrm{E}+02$ & $0.00 \mathrm{E}+00$ (with parent) & $0.00 \mathrm{E}+00$ \\
\hline $234 \mathrm{U}$ & $2.42 \mathrm{E}+00$ & $2.88 \mathrm{E}-02$ & $6.97 \mathrm{E}-02$ \\
\hline $238 \mathrm{Pu}$ & $1.23 \mathrm{E}+00$ & $3.32 \mathrm{E}-02$ & $4.08 \mathrm{E}-02$ \\
\hline $238 \mathrm{U}$ & $2.47 \mathrm{E}+00$ & $2.53 \mathrm{E}-02$ & $6.25 \mathrm{E}-02$ \\
\hline $239 \mathrm{Pu}$ & $2.61 \mathrm{E}+02$ & $3.11 \mathrm{E}-02$ & $8.11 \mathrm{E}+00$ \\
\hline $240 \mathrm{Pu}$ & $3.02 \mathrm{E}+01$ & $3.12 \mathrm{E}-02$ & $9.41 \mathrm{E}-01$ \\
\hline $241 \mathrm{Am}$ & $9.82 \mathrm{E}+01$ & $3.34 \mathrm{E}-02$ & $3.28 \mathrm{E}+00$ \\
\hline Sum & & & $65.5(223 \mathrm{BTU} / \mathrm{hr})$ \\
\hline
\end{tabular}

${ }^{1}$ From TWINS download, September 12, 2012, decay date January 1, 2008

${ }^{2}$ From HNF-EP-0063, Hanford Site Solid Waste Acceptance Criteria, Rev 14 (reissue), August 11, 2008

\subsection{Leak Rate Estimate}

Rearranging the volumetric change rate equation from Section 4.3 gives:

leak rate $=$ volumetric change rate - intrusion rate - evaporation rate $-\Sigma$ other

In this formula the volumetric change rate and $[\Sigma$ other] may be positive or negative, but the intrusion rate is always positive or zero and the evaporation rate is always negative or zero. Since the leak rate is always negative or zero, if the calculated leak rate is positive then the assumed evaporation rate is too high and/or the assumed intrusion rate or [ $\Sigma$ other] are too low.

Summarizing the values from the previous sections:

- From Section 4.2:

- The volume change rate for each day from July 13, 1995 to June 13, 2013 is calculated as described for Figure 25.

- No volume change rate is estimated from June 13, 2013 to September 25, 2013. It is unknown whether the intrusion rate increased for this period and/or the leak rate decreased, a volume change rate of zero is used.

○ The volume change rate from September 25, 2013 to January 1, 2014 is assumed to be $-1.6 \mathrm{gal} / \mathrm{d}$.

- From Section 4.3, [ $\Sigma$ other] is assumed to be $+5 \mathrm{gal} / \mathrm{yr}(0.014 \mathrm{gal} / \mathrm{d})$ 


\section{RPP-RPT-54964, Revision 2}

- From Section 4.4 the intrusion rate is assumed to range from zero to $0.81 \mathrm{gal} / \mathrm{d}$ (0 to $300 \mathrm{gal} / \mathrm{yr}$ ).

- From Section 4.5 the evaporation rate is assumed to average $-0.13 \mathrm{gal} / \mathrm{d}$ ( $-48 \mathrm{gal} / \mathrm{yr})$.

The leak rate equation is thus:

leak rate $=$ volumetric change rate - intrusion rate $-(-0.13 \mathrm{gal} / \mathrm{d})-0.014 \mathrm{gal} / \mathrm{d}$

Rearranging:

$$
\text { leak rate }=\text { volumetric change rate }- \text { intrusion rate }+0.12 \text { gal } / d
$$

Figure 28 plots a calculated leak rate using the above equation as a function of constant intrusion rates ranging from zero to $0.81 \mathrm{gal} / \mathrm{d}$ (zero to $300 \mathrm{gal} / \mathrm{yr}$ ). Since a leak rate can't be positive, the following conclusions can be drawn from Figure 28:

1. The average intrusion rate must be slightly greater than $125 \mathrm{gal} / \mathrm{yr}$ (the calculated leak rate becomes negative in July 1995 at about $131 \mathrm{gal} / \mathrm{yr}$ ), or,

2. The evaporation rate must be lower (less negative) than the $-48 \mathrm{gal} / \mathrm{yr}$ estimated, or,

3. There needs to be a different value for $[\Sigma$ other $]$ than $+5 \mathrm{gal} / \mathrm{yr}$, or,

4. The volume change rate in Figure 25 is erroneous, or,

5. Both the leak rate and the intrusion rate vary.

There are an infinite number of combinations of assumptions for intrusion rates, evaporation rate and $[\Sigma$ other $]$ values to use that will still satisfy the equation

$$
\text { leak rate }=\text { volumetric change rate }- \text { intrusion rate }- \text { evaporation rate }-\Sigma \text { other }
$$

The lowest average intrusion rate that gives a non-positive leak rate for tank T-111 after mid-July 1995 is $\sim 131$ gal/yr. Figure 29 plots the tank T-111 leak rate for a constant $131 \mathrm{gal} / \mathrm{yr}$ average intrusion rate.

There is no way to know exactly when the tank T-111 leak restarted after 1995, or if it never stopped after saltwell pumping in 1994 and its presence masked by an intrusion. However, the inferences that most closely match the data are:

- The average intrusion rate into tank T-111 has been around $130 \mathrm{gal} / \mathrm{yr}$, but has probably varied widely.

- The leak from tank T-111 appears to have restarted in the 2000 to 2003 time frame, assuming there was not a major decrease in the intrusion rate at that time. If there was a major decrease in the intrusion rate the current tank leak period may have begun earlier.

- The leak rate progressively increased, reaching a maximum rate of about $-3 \mathrm{gal} / \mathrm{d}$ $(-1,100 \mathrm{gal} / \mathrm{yr})$ in June 2013. The intrusion rate and leak rate balanced each other (after accounting for evaporation and other factors) from July to September 2013. The leak rate then averaged about $-1.8 \mathrm{gal} / \mathrm{d}$ (-660 gal/yr) from September to January 2014. The $-1.8 \mathrm{gal} / \mathrm{d}$ is the value from Figure 28 for a $125 \mathrm{gal} / \mathrm{yr}$ intrusion rate. 
RPP-RPT-54964, Revision 2

Figure 28 Calculated Tank T-111 Leak Rate as Function of Assumed Intrusion Rate

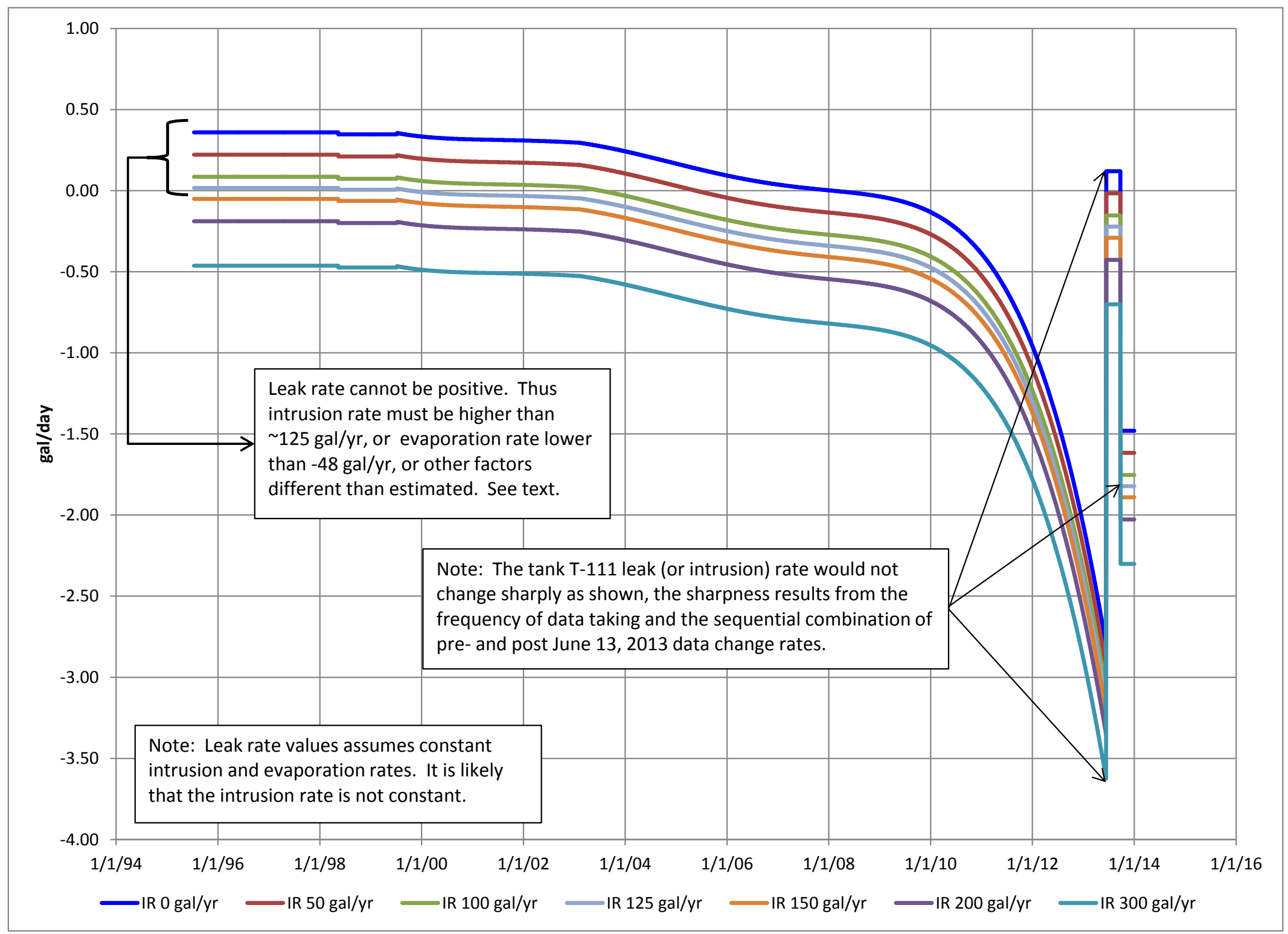


RPP-RPT-54964, Revision 2

Figure 29 Calculated Tank T-111 Leak Rate for An Average 131 gal/yr Intrusion Rate

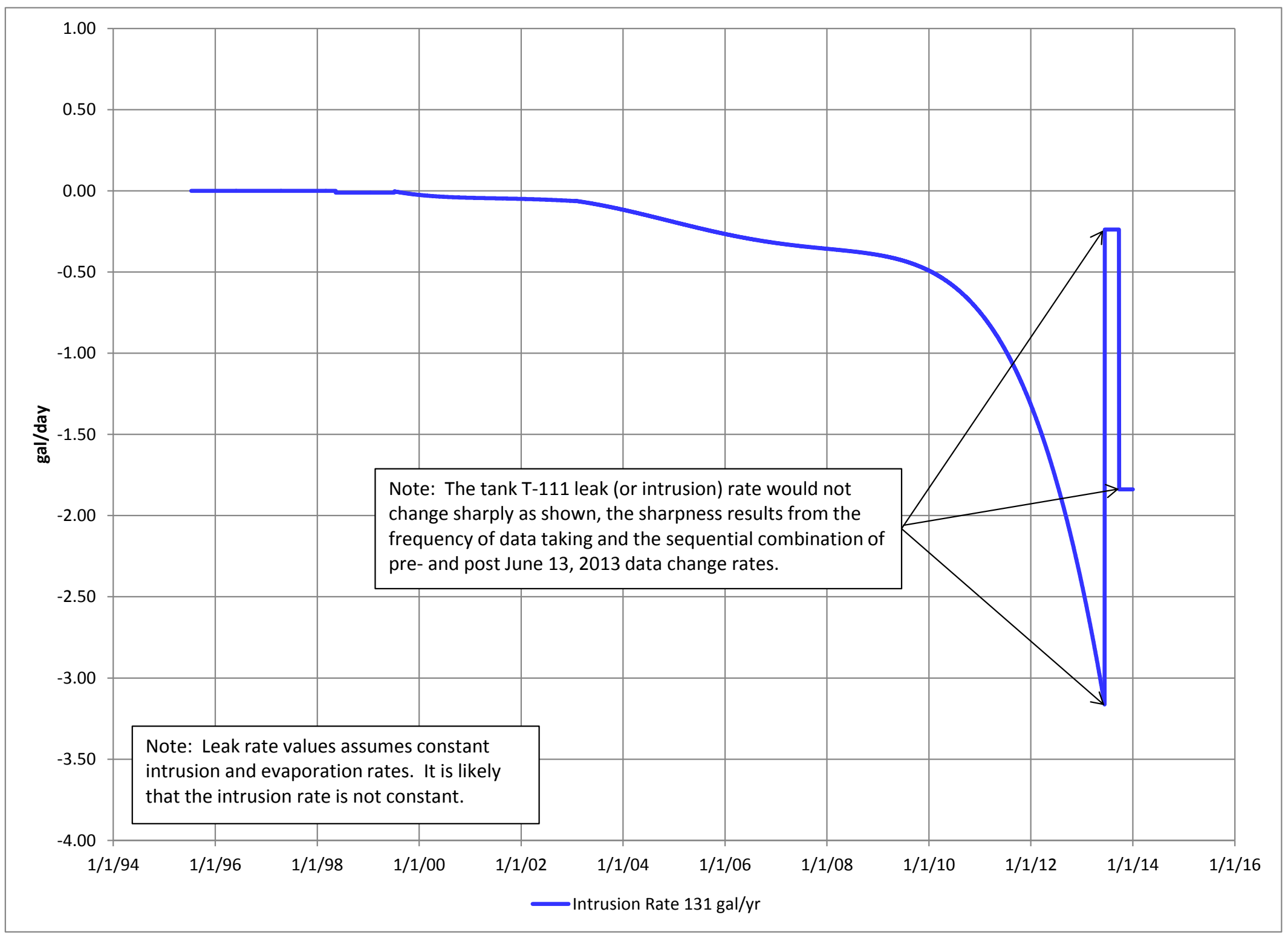




\subsection{Leak Volume Estimate}

An estimated post-July 1995 leak volume was estimated by assuming a constant $131 \mathrm{gal} / \mathrm{yr}$ intrusion rate, calculating a daily leak rate, and then summing up the daily leak volumes. An intrusion rate of $131 \mathrm{gal} / \mathrm{yr}$ is the minimum necessary to calculate a non-positive leak rate in 1995 using a $-48 \mathrm{gal} / \mathrm{yr}$ evaporation rate and $+5 \mathrm{gal} / \mathrm{yr}$ for [ $\Sigma$ other].

Using this method, the first calculated negative leak rate occurred in mid-May 1998. It was a negligible value of $-0.01 \mathrm{gal} / \mathrm{d}$. The cumulative leak volume didn't reach $100 \mathrm{gal}$ until late March 2004. It reached 500 gal in mid-April 2008 and as of January 1, 2014 the calculated leak volume was 2,640 gal.

\subsection{Conclusions}

It is the conclusion of this document that the level changes in tank T-111 are due to a combination of intrusion and leaking.

Assuming the evaporation and intrusion rates in this document are reasonable:

- The leak rate from tank T-111 reached a maximum of slightly over -3 gal/day in June 2013 and as of January 1, 2014 was approximately -1.8 gal/day

- The post 1994 leak volume as of January 1, 2014 is approximately 2,600 gal. This assumes no leak between June 13 and September 25, 2013. If it is assumed there was a constant $131 \mathrm{gal} / \mathrm{yr}$ intrusion rate during between June 13 and September 25, 2013 the leak volume is about 25 gal higher. 
RPP-RPT-54964, Revision 2

\subsection{References}

CLO-WO-1250, Work Package 241-T, 111 [sic] Enraf Inspection, September 4, 2007, CH2M Hill Hanford Group, Inc., Richland, Washington.

BPF-73550, Specifications for Construction of Composite Storage Tanks Bldg. No. 241, Hanford Engineer Works, Project 9536, January 11, 1944, du Pont Company, IDMS Accession Number 10021104347.

DRI Forms -Direct Reading Instrument monitoring results were obtained from the Site Wide Industrial Hygiene Database (SWIHD). The Tank Farm portion of SWIHD is maintained by the Tank Farm Industrial Hygiene Programs organization. The SWIHD is located on a restricted area of IDMS with access controlled by Industrial Hygiene and Safety (IHS) personnel.

Excel file BP Correlation with DB Connect, SVF-1002, June 27, 2005, CH2M HILL Hanford Group Inc. and Lockheed Martin Services Inc., Richland Washington.

HNF-EP-0063, Hanford Site Solid Waste Acceptance Criteria, Rev 14 (reissue), 2008, Fluor Hanford, Inc., Richland, Washington.

HNF-EP-0182, 2013, Waste Tank Summary Report for Month Ending October 31, 2013, Rev. 307, Washington River Protection Solutions, LLC, Richland, Washington.

HNF-SD-RE-TI-178, Single-Shell Tank Interim Stabilization Record, Rev 9(a), 2007, CH2M Hill Hanford Group, Inc., Richland, Washington.

Internal Memos: R. E. Wheeler to R. L. Walser, Analysis of Tank Farm Samples Sample: T-3304, 111-T, June 7, 1974 and R. E. Wheeler to R. L. Walser, Analysis of Tank Farm Samples Sample: T-4893, 111-T, IDMS Accession \#1007130273, September 24, 1974), Atlantic Richfield Hanford Company, Richland, Washington.

OSD-T-151-00031, Operating Specifications for Tank Farm Leak Detection and Single-Shell Tank Intrusion Detection, Revision 3, September 2013, Washington River Protection Solutions, Richland, Washington.

RPP-5926, 2013, Steady-State Flammable Gas Release Rate Calculation and Lower Flammability Level Evaluation for Hanford Tank Waste, Rev 13, February, 2013, Washington River Protection Solutions, Richland, Washington.

RPP-RPT-26836, 2010, Gas Retention and Release from Hanford Site High Shear Strength Waste, Rev 0, April, 2010, Washington River Protection Solutions, Richland, Washington.

RPP-RPT-43169, 2009 Auto TCR for Tank 241-T-111, Rev 0, 2009, Washington River Protection Solutions, Richland, Washington.

RPP-RPT-54305, Initial Assessment for Potential Gas Release Events in Hanford Site Deep Sludge Double-Shell Tank Waste, 2013, Washington River Protection Solutions, Richland, Washington.

RPP-RPT-54964, 2013, Evaluation of Tank 241-T-111 Level Data and In-Tank Video Inspection, Rev.1, Washington River Protection Solutions, LLC, Richland, Washington. 
RPP-RPT-54981, 2013, Initial Evaluation of Fourteen Tanks with Decreasing Baselines Selected for Review in RPP-PLAN-55113, Revision 1, Rev. 0, Washington River Protection Solutions, LLC, Richland, Washington.

RPP-RPT-55084, Hanford 241-T Farm Leak Inventory Assessment Report, Rev 0, Washington River Protection Solutions, LLC, Richland, Washington.

SD-WM-TI-356, Waste Storage Tank Status and Leak Detection Criteria, Revision 0, Volume 2, September, 1988, Westinghouse Hanford Company, Richland, Washington.

TFC-ENG-CHEM-D-42, Tank Leak Assessment Process, latest revision, Washington River Protection Solutions, Richland, Washington.

TFC-WO-09-1853, Work Package 241-T, 111 Enraf Inspection, September 10, 2009, Washington River Protection Solutions, Richland, Washington.

TFC-WO-11-3306, Work Package 241-T, 111 Enraf Inspection, December 30, 2011, Washington River Protection Solutions, Richland, Washington.

TFC-WO-12-5616, 241-T-111 Perform Video Inspection, February 11, 2013 and March 20, 2013, Washington River Protection Solutions, Richland, Washington.

TWINS, Tank Waste Information Network System, database available on the Hanford Local Area Network (HLAN) at https://twins.labworks.org/twinsdata/Forms/About.aspx

U. S. Geological Survey, see website details for 4 drips per $\mathrm{mL}$ at: http://ga.water.usgs.gov/edu/sc4.html

WRPS-PER 2012-1977, Problem Evaluation Request 2012-1977 - ...Tank 241-T-111 indicates that waste level has a decreasing liquid level trend..., November 27, 2012, Washington River Protection Solutions, Richland, Washington. 


\section{Table 7 References Used for Level Data}

The surface and interstitial liquid level data used in this document were obtained from the following sources. Surface levels prior to September 30, 1972 were calculated from waste volumes given in in the monthly, quarterly and semi-annual reports listed below using the equation: liquid level $[$ in. $]=(($ volume $[$ gal $]-12,500) \div 2,750)+12$.

\begin{tabular}{|c|c|}
\hline 1 & $\begin{array}{l}\text { Surface level and interstitial liquid level for dates between } 1 / 1 / 1980 \text { and 4/1/2013 } \\
\text { obtained from TWINS download on April 1, 2013. Data from April 2, 2013 to January } \\
\text { 1, } 2014 \text { obtained from TWINS download on January } 6,2014\end{array}$ \\
\hline 2 & $\begin{array}{l}\text { HW-59204, Waste Status Summary January 1, } 1959 \text { - January 31, 1959, February 1959, } \\
\text { General Electric, Richland, Washington. }\end{array}$ \\
\hline 3 & $\begin{array}{l}\text { HW-59586, Waste Status Summary February 1, } 1959 \text { - February 28, 1959, March 1959, } \\
\text { General Electric, Richland, Washington. }\end{array}$ \\
\hline 4 & $\begin{array}{l}\text { HW-60065, Waste Status Summary March 1, } 1959 \text { - March 31, 1959, April 1959, } \\
\text { General Electric, Richland, Washington. }\end{array}$ \\
\hline 5 & $\begin{array}{l}\text { HW-60419, Waste Status Summary April 1, } 1959 \text { - April 30, 1959, May 1959, General } \\
\text { Electric, Richland, Washington. }\end{array}$ \\
\hline 6 & $\begin{array}{l}\text { HW-60738, Waste Status Summary May 1, } 1959 \text { - May 31, 1959, June 1959, General } \\
\text { Electric, Richland, Washington. }\end{array}$ \\
\hline 7 & $\begin{array}{l}\text { HW-61095, Waste Status Summary June 1, } 1959 \text { - June 30, 1959, July 1959, General } \\
\text { Electric, Richland, Washington. }\end{array}$ \\
\hline 8 & $\begin{array}{l}\text { HW-61582, Waste Status Summary July 1, } 1959-\text { July 31, 1959, August 1959, General } \\
\text { Electric, Richland, Washington. }\end{array}$ \\
\hline 9 & $\begin{array}{l}\text { HW-61952, Waste Status Summary August 1, } 1959 \text { - August 31, 1959, September 1959, } \\
\text { General Electric, Richland, Washington. }\end{array}$ \\
\hline 10 & $\begin{array}{l}\text { HW-62421, Waste Status Summary September 1, } 1959 \text { - September 30, 1959, October } \\
\text { 1959, General Electric, Richland, Washington. }\end{array}$ \\
\hline 11 & $\begin{array}{l}\text { HW-62723, Waste Status Summary October } 1 \text { - 31, 1959, November 1959, General } \\
\text { Electric, Richland, Washington. }\end{array}$ \\
\hline 12 & $\begin{array}{l}\text { HW-63083, Waste Status Summary November } 1 \text { - 30, 1959, December 1959, General } \\
\text { Electric, Richland, Washington. }\end{array}$ \\
\hline 13 & $\begin{array}{l}\text { HW-63559, Waste Status Summary December } 1 \text { - 31, 1959, January 1960, General } \\
\text { Electric, Richland, Washington. }\end{array}$ \\
\hline 14 & $\begin{array}{l}\text { HW-63896, Waste Status Summary January } 1 \text { - 31, 1960, February 1960, General } \\
\text { Electric, Richland, Washington. }\end{array}$ \\
\hline 15 & $\begin{array}{l}\text { HW-64373, Waste Status Summary February } 1 \text { - 29, 1960, March 1960, General } \\
\text { Electric, Richland, Washington. }\end{array}$ \\
\hline 16 & $\begin{array}{l}\text { HW-64810, Waste Status Summary March } 1 \text { - 31, 1960, April 1960, General Electric, } \\
\text { Richland, Washington. }\end{array}$ \\
\hline
\end{tabular}




\begin{tabular}{|c|c|}
\hline 17 & $\begin{array}{l}\text { HW-65272, Waste Status Summary April } 1 \text { - 31, 1960, May 1960, General Electric, } \\
\text { Richland, Washington. }\end{array}$ \\
\hline 18 & $\begin{array}{l}\text { HW-65643, Waste Status Summary May } 1 \text { - 31, 1960, June 1960, General Electric, } \\
\text { Richland, Washington. }\end{array}$ \\
\hline 19 & $\begin{array}{l}\text { HW-66187, Waste Status Summary June } 1 \text { - June 30, 1960, July 1960, General Electric, } \\
\text { Richland, Washington. }\end{array}$ \\
\hline 20 & $\begin{array}{l}\text { HW-66557, Waste Status Summary July } 1 \text { - July 31, 1960, August 1960, General } \\
\text { Electric, Richland, Washington. }\end{array}$ \\
\hline 21 & $\begin{array}{l}\text { HW-66827, Waste Status Summary August 1-August 31, 1960, September 1960, } \\
\text { General Electric, Richland, Washington. }\end{array}$ \\
\hline 22 & $\begin{array}{l}\text { HW-67696, Waste Status Summary September } 1 \text { - September 30, 1960, November } 1960 \text {, } \\
\text { General Electric, Richland, Washington. }\end{array}$ \\
\hline 23 & $\begin{array}{l}\text { HW-67705, Waste Status Summary October } 1 \text { - October 31, 1960, November 1960, } \\
\text { General Electric, Richland, Washington. }\end{array}$ \\
\hline 24 & $\begin{array}{l}\text { HW-68291, Waste Status Summary November } 1 \text { - November 30, 1960, January 1961, } \\
\text { General Electric, Richland, Washington. }\end{array}$ \\
\hline 25 & $\begin{array}{l}\text { HW-68292, Waste Status Summary December } 1 \text { - December 31, 1960, January 1961, } \\
\text { General Electric, Richland, Washington. }\end{array}$ \\
\hline 26 & $\begin{array}{l}\text { HW-71610, Waste Status Summary January 1, } 1961 \text { Through June 30, 1961, November } \\
\text { 1961, General Electric, Richland, Washington. }\end{array}$ \\
\hline 27 & $\begin{array}{l}\text { HW-72625, Waste Status Summary July 1, } 1961 \text { Through December 31, 1961, February } \\
\text { 1962, General Electric, Richland, Washington. }\end{array}$ \\
\hline 28 & $\begin{array}{l}\text { HW-74647, Waste Status Summary January 1, } 1962 \text { Through June 30, 1962, August } \\
\text { 1962, General Electric, Richland, Washington. }\end{array}$ \\
\hline 29 & $\begin{array}{l}\text { HW-76223, Waste Status Summary July 1, } 1962 \text { Through December 31, 1962, January } \\
\text { 1963, General Electric, Richland, Washington. }\end{array}$ \\
\hline 30 & $\begin{array}{l}\text { HW-78279, Waste Status Summary January 1, } 1963 \text { Through June 30, 1963, July 1963, } \\
\text { General Electric, Richland, Washington. }\end{array}$ \\
\hline 31 & $\begin{array}{l}\text { HW-80379, Waste Status Summary July 1, } 1963 \text { Through December 31, 1963, January } \\
\text { 1964, General Electric, Richland, Washington. }\end{array}$ \\
\hline 32 & $\begin{array}{l}\text { HW-83308, Waste Status Summary January 1, } 1964 \text { Through June 30, 1964, July 1964, } \\
\text { General Electric, Richland, Washington. }\end{array}$ \\
\hline 33 & $\begin{array}{l}\text { RL-SEP-260, Waste Status Summary July 1, } 1964 \text { Through December 31, 1964, January } \\
\text { 1965, General Electric, Richland, Washington. }\end{array}$ \\
\hline 34 & $\begin{array}{l}\text { RL-SEP-659, Waste Status Summary January 1, } 1965 \text { through June 30, 1965, August } \\
\text { 1965, General Electric, Richland, Washington. }\end{array}$ \\
\hline 35 & $\begin{array}{l}\text { RL-SEP-821, Waste Status Summary July 1, } 1965 \text { through September 30, 1965, October } \\
\text { 1965, General Electric, Richland, Washington. }\end{array}$ \\
\hline
\end{tabular}




\begin{tabular}{|c|c|}
\hline 36 & $\begin{array}{l}\text { RL-SEP-923, Waste Status Summary October 1, } 1965 \text { Through December 31, 1965, } \\
\text { January 1966, General Electric, Richland, Washington. }\end{array}$ \\
\hline 37 & $\begin{array}{l}\text { ISO-226, Waste Status Summary January 1, } 1966 \text { Through March 31, 1966, April 1966, } \\
\text { ISOCHEM Inc., Richland, Washington. }\end{array}$ \\
\hline 38 & $\begin{array}{l}\text { ISO-404, Waste Status Summary April , 1, } 1966 \text { Through June 30, 1966, July 1966, } \\
\text { ISOCHEM Inc., Richland, Washington. }\end{array}$ \\
\hline 39 & $\begin{array}{l}\text { ISO-538, Waste Status Summary July 1, } 1966 \text { Through September 30, 1966, October } \\
\text { 1966, ISOCHEM Inc., Richland, Washington. }\end{array}$ \\
\hline 40 & $\begin{array}{l}\text { ISO-674, Waste Status Summary October 1, } 1966 \text { Through December 31, 1966, January } \\
\text { 1967, ISOCHEM Inc., Richland, Washington. }\end{array}$ \\
\hline 41 & $\begin{array}{l}\text { ISO-806, Waste Status Summary January 1, } 1967 \text { Through March 31, 1967, April 1967, } \\
\text { ISOCHEM Inc., Richland, Washington. }\end{array}$ \\
\hline 42 & $\begin{array}{l}\text { ISO-967, Waste Status Summary April 1, } 1967 \text { Through June 30, 1967, July 1967, } \\
\text { ISOCHEM Inc., Richland, Washington. }\end{array}$ \\
\hline 43 & $\begin{array}{l}\text { ARH-95, Waste Status Summary July 1, } 1967 \text { Through September 30, 1967, October } \\
\text { 1967, Atlantic Richfield Hanford Company, Richland, Washington. }\end{array}$ \\
\hline 44 & $\begin{array}{l}\text { ARH-326, Waste Status Summary October 1, } 1967 \text { Through December 31, 1967, January } \\
\text { 1968, Atlantic Richfield Hanford Company, Richland, Washington. }\end{array}$ \\
\hline 45 & $\begin{array}{l}\text { ARH-534, Waste Status Summary January 1, } 1968 \text { Through March 31, 1968, April 1968, } \\
\text { Atlantic Richfield Hanford Company, Richland, Washington. }\end{array}$ \\
\hline 46 & $\begin{array}{l}\text { ARH-721, Waste Status Summary April 1, } 1968 \text { Through June 30, 1968, July 1968, } \\
\text { Atlantic Richfield Hanford Company, Richland, Washington. }\end{array}$ \\
\hline 47 & $\begin{array}{l}\text { ARH-871, Waste Status Summary July 1, } 1968 \text { Through September 30, 1968, October } \\
\text { 1968, Atlantic Richfield Hanford Company, Richland, Washington. }\end{array}$ \\
\hline 48 & $\begin{array}{l}\text { ARH-1061, Waste Status Summary October 1, } 1968 \text { Through December 31, 1968, } \\
\text { January 1969, Atlantic Richfield Hanford Company, Richland, Washington. }\end{array}$ \\
\hline 49 & $\begin{array}{l}\text { ARH-1200 A, Waste Status Summary January 1, } 1969 \text { Through March 31, 1969, April } \\
\text { 1969, Atlantic Richfield Hanford Company, Richland, Washington. }\end{array}$ \\
\hline 50 & $\begin{array}{l}\text { ARH-1200 B, Waste Status Summary April 1, } 1969 \text { Through June 30, 1969, July 1969, } \\
\text { Atlantic Richfield Hanford Company, Richland, Washington. }\end{array}$ \\
\hline 51 & $\begin{array}{l}\text { ARH-1200 C, Waste Status Summary July 1, } 1969 \text { Through September 30, 1969, October } \\
\text { 1969, Atlantic Richfield Hanford Company, Richland, Washington. }\end{array}$ \\
\hline 52 & $\begin{array}{l}\text { ARH-1200 D, Waste Status Summary October 1, } 1969 \text { Through December 31, 1969, } \\
\text { January 1970, Atlantic Richfield Hanford Company, Richland, Washington. }\end{array}$ \\
\hline 53 & $\begin{array}{l}\text { ARH-1666 A, Waste Status Summary January 1, } 1970 \text { Through March 31, 1970, April } \\
\text { 1970, Atlantic Richfield Hanford Company, Richland, Washington. }\end{array}$ \\
\hline 54 & $\begin{array}{l}\text { ARH-1666 B, Waste Status Summary April 1, } 1970 \text { Through June 30, 1970, July 1970, } \\
\text { Atlantic Richfield Hanford Company, Richland, Washington. }\end{array}$ \\
\hline
\end{tabular}




\begin{tabular}{|c|c|}
\hline 55 & $\begin{array}{l}\text { ARH-1666 C, Waste Status Summary July 1, } 1970 \text { Through September 30, 1970, October } \\
\text { 1970, Atlantic Richfield Hanford Company, Richland, Washington. }\end{array}$ \\
\hline 56 & $\begin{array}{l}\text { ARH-1666 D, Waste Status Summary October 1, } 1970 \text { Through December 31, 1970, } \\
\text { January 1971, Atlantic Richfield Hanford Company, Richland, Washington. }\end{array}$ \\
\hline 57 & $\begin{array}{l}\text { ARH-2074 A, Waste Status Summary January 1, } 1971 \text { Through March 31, 1971, April } \\
\text { 1971, Atlantic Richfield Hanford Company, Richland, Washington. }\end{array}$ \\
\hline 58 & $\begin{array}{l}\text { ARH-2074 B, Waste Status Summary April 1, } 1971 \text { Through June 30, 1971, July 1971, } \\
\text { Atlantic Richfield Hanford Company, Richland, Washington. }\end{array}$ \\
\hline 59 & $\begin{array}{l}\text { ARH-2074 C, Waste Status Summary July 1, } 1971 \text { Through September 30, 1971, October } \\
\text { 1971, Atlantic Richfield Hanford Company, Richland, Washington. }\end{array}$ \\
\hline 60 & $\begin{array}{l}\text { ARH-2074 D, Waste Status Summary October 1, } 1971 \text { Through December 31, 1971, } \\
\text { January 1972, Atlantic Richfield Hanford Company, Richland, Washington. }\end{array}$ \\
\hline 61 & $\begin{array}{l}\text { ARH-2456 A, Waste Status Summary January 1, } 1972 \text { Through March 31, 1972, April } \\
\text { 1972, Atlantic Richfield Hanford Company, Richland, Washington. }\end{array}$ \\
\hline 62 & $\begin{array}{l}\text { ARH-2456 B, Waste Status Summary April 1, } 1972 \text { Through June 30, 1972, July 1972, } \\
\text { Atlantic Richfield Hanford Company, Richland, Washington. }\end{array}$ \\
\hline 63 & $\begin{array}{l}\text { ARH-2456 C, Waste Status Summary July 1, } 1972 \text { Through September 30, 1972, October } \\
\text { 1972, Atlantic Richfield Hanford Company, Richland, Washington. }\end{array}$ \\
\hline 64 & $\begin{array}{l}\text { IDMS Accession number } 1107190725 \text { - Managed Information - Electronic Records - } \\
\text { Tank Operations/WRPS - } 200 \text { Area Tank Farm Operations - Historical Records - Liquid } \\
\text { and Temperature Readings for the Tanks - Surface Level Graphs - T-Farm Surface } \\
\text { Levels - } 1973\end{array}$ \\
\hline 65 & $\begin{array}{l}\text { IDMS Accession number } 1007140438 \text { - Managed Information - Electronic Records - } \\
\text { Tank Operations/WRPS - } 200 \text { Area Tank Farm Operations - Historical Records - Liquid } \\
\text { and Temperature Readings for the Tanks - } 200 \mathrm{~W} 07 / 27 / 1973 \text { thru 08/10/1973 }\end{array}$ \\
\hline 66 & $\begin{array}{l}\text { Data sheets located in Hanford Site Storage Box 58069, obtained from Records Holding, } \\
\text { stored in Seattle. }\end{array}$ \\
\hline 67 & $\begin{array}{l}\text { Data sheets located in Hanford Site Storage Box 58070, obtained from Records Holding, } \\
\text { stored in Seattle. }\end{array}$ \\
\hline 68 & $\begin{array}{l}\text { Data sheets located in Hanford Site Storage Box 58072, obtained from Records Holding, } \\
\text { stored in Seattle. }\end{array}$ \\
\hline 69 & $\begin{array}{l}\text { Data sheets located in Hanford Site Storage Box 58106, obtained from Records Holding, } \\
\text { stored in Seattle. }\end{array}$ \\
\hline 70 & $\begin{array}{l}\text { Data sheets and/or log sheets located in Hanford Site Storage Box 111507, obtained from } \\
\text { Records Holding, stored in Seattle. }\end{array}$ \\
\hline 71 & $\begin{array}{l}\text { Data sheets and/or log sheets located in Hanford Site Storage Box 111508, obtained from } \\
\text { Records Holding, stored in Seattle. }\end{array}$ \\
\hline
\end{tabular}

